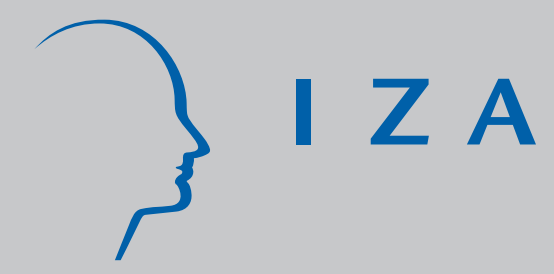

IZA DP No. 451

The Complementarity of Language and Other Human Capital: Immigrant Earnings in Canada

Barry R. Chiswick

Paul W. Miller

March 2002 


\title{
The Complementarity of Language and Other Human Capital: Immigrant Earnings in Canada
}

\author{
Barry R. Chiswick \\ University of Illinois, Chicago and IZA, Bonn \\ Paul W. Miller \\ University of Western Australia
}

Discussion Paper No. 451

March 2002

\author{
IZA \\ P.O. Box 7240 \\ D-53072 Bonn \\ Germany \\ Tel.: +49-228-3894-0 \\ Fax: +49-228-3894-210 \\ Email: iza@iza.org
}

This Discussion Paper is issued within the framework of IZA's research area Mobility and Flexibility of Labor. Any opinions expressed here are those of the author(s) and not those of the institute. Research disseminated by IZA may include views on policy, but the institute itself takes no institutional policy positions.

The Institute for the Study of Labor (IZA) in Bonn is a local and virtual international research center and a place of communication between science, politics and business. IZA is an independent, nonprofit limited liability company (Gesellschaft mit beschränkter Haftung) supported by the Deutsche Post AG. The center is associated with the University of Bonn and offers a stimulating research environment through its research networks, research support, and visitors and doctoral programs. IZA engages in (i) original and internationally competitive research in all fields of labor economics, (ii) development of policy concepts, and (iii) dissemination of research results and concepts to the interested public. The current research program deals with (1) mobility and flexibility of labor, (2) internationalization of labor markets, (3) the welfare state and labor markets, (4) labor markets in transition countries, (5) the future of labor, (6) evaluation of labor market policies and projects and (7) general labor economics.

IZA Discussion Papers often represent preliminary work and are circulated to encourage discussion. Citation of such a paper should account for its provisional character. A revised version may be available on the IZA website (www.iza.org) or directly from the author. 


\section{ABSTRACT \\ The Complementarity of Language and Other Human Capital: Immigrant Earnings in Canada}

This paper analyzes the effects of language practice on earnings among adult male immigrants in Canada using the 1991 Census. Earnings are shown to increase with schooling, pre-immigration experience and duration in Canada, as well as with proficiency in the official languages (English and French). Using selectivity correction techniques, it is shown that there is complementarity between language skills and both schooling and preimmigration experience. That is, greater proficiency in the official languages enhances the effects on earnings of schooling and pre-immigration labor market experience. Language proficiency and post-migration experience appear to be substitutes, that is, those with greater proficiency have a smaller effect of time in Canada on earnings.

JEL Classification: I21, J24, J31, J61

Keywords: Immigrants, human capital, language skills, schooling, earnings, Canada

Barry R. Chiswick

Department of Economics (MC 144)

College of Business Administration

601 S. Morgan Street (Room $2103 \mathrm{UH}$ )

Chicago, IL 60607-7121

USA

Tel.: +1 (312) 9962683

Fax: +1 (312) 9963344

Email: brchis@uic.edu

\footnotetext{
* We appreciate the comments received from the participants at the Conference on Immigration with an International Perspective, Vancouver, January 1999 and the Applications Workshop, Department of Economics, University of Chicago, May 1999. This paper was written, in part, while Chiswick was John M. Olin Visiting Professor, Graduate School of Business, University of Chicago and while Miller was Visiting Professor, Department of Economics, University of Illinois at Chicago. Partial financial support for this project was provided by the Embassy of Canada, Washington, D.C., the George J. Stigler Center for the Study of the Economy and the State, University of Chicago, and the Vancouver Centre of Excellence: Research on Immigration and Integration in the Metropolis (RIIM). An earlier version of this paper was RIIM Working Paper \#00-13, September 2000.
} 


\section{INTRODUCTION}

Language skills are a form of human capital. As with other forms of human capital, language skills are created at a sacrifice of time and other resources, are embodied in the person and are productive. Previous research has shown for several immigrant receiving countries that greater proficiency in the destination language enhances labor market earnings and that this investment provides a high rate of return (see, for example, Chiswick and Miller, 1995). Destination language proficiency is presumably also productive in consumption activities, although we do not know of empirical research on this issue.

The purpose of this paper is to extend the analysis of destination language skills among immigrants. It does this in two ways. First, it extends the theoretical work by hypothesizing and then testing for whether destination language skills appear to be complements or substitutes in generating earnings with respect to other kinds of human capital, namely schooling and pre- and post- migration labor market experience. Second, it uses data from the 1991 Census of Canada to estimate the effect of language usage on earnings among immigrants in Canada. Previous studies for Canada relied primarily on the 1981 Census. The analysis of earnings uses the now standard human capital earnings function adjusted to account for immigrant assimilation. The earnings function is estimated overall and using selectivity correction techniques separately by language use categories.

Section II outlines the model of the relation between destination language skills and other forms of human capital. Section III describes the data used in the analysis, the 1991 Census of Canada. Section IV presents the human capital earnings function that forms the basis of the empirical analysis and reports the findings of the analysis. Section $\mathrm{V}$ is the summary and conclusion.

\section{THE MODEL}

This study is concerned with the impact on earnings of the destination language proficiency of immigrants. Greater proficiency in the destination language can enhance earnings by enabling the immigrants to find a better labor market match between heir skills 
and the requirements of employers (more efficient job search). Language proficiency can also have a direct impact on productivity through more efficient communication, orally and in writing, with supervisors, subordinates, peers, suppliers and customers (higher productivity on the job). This greater efficiency in communication raises the productivity of labor. ${ }^{1}$ Hence, earnings among immigrants are expected to be a rising function of the immigrant's proficiency in the destination language.

Destination language proficiency can have indirect impacts on labor market earnings through the effect on the productivity of other forms of human capital. For example, greater destination language proficiency may increase the returns from schooling and labor market experience. Schooling and pre-immigration labor market experience may be of little, if any, value to an immigrant with no knowledge of the destination language. In spite of a high level of schooling and job training this person may be little different from an unskilled worker as far as the destination labor market is concerned. As this immigrant's destination language skills improve, the productivity of the schooling and pre-immigration experience in the destination labor market increases. Hence, it would be hypothesized that destination language skills have a complementary relationship in the labor market with respect to schooling and pre-immigration labor market experience.

There are various forms of destination-specific human capital, only one of which is destination language skills. Those making greater investments in destination language skills may also make greater (or lesser) investments in other forms of destination-specific human capital. These other forms of human capital are not measured directly but are reflected in the empirical analysis by the variable for duration of residence or length of stay in the destination. If there is a lesser intensity of investment in post-migration human capital other than language skills the effect of duration on earnings is lowered (flattened) for two reasons. One is that foregone earnings are lower if there is less investment, and this mitigates the

1 The Biblical story of the Tower of Babel is relevant here (Genesis, Chapter 11). To thwart the efforts of people to work together to build a tower that would reach Heaven, God inflicted on the populous a multitude of languages. As a result of the increased costs of communication, as the story goes, the Tower was never completed. 
reduction in earnings in the investment period. The other is that there is a smaller increase in earnings from the post-migration investments. Then, if language proficiency and other forms of post-migration investments are substitute forms of investment, those with greater destination language proficiency will have a smaller increase in earnings with duration, holding language skills constant. On the other hand, if these investments are complementary, that is, if those who invest more in language skills also invest more in other forms of post-migration human capital, those with greater destination language proficiency will have a steeper rise in earnings with duration, other things being the same.

For a fixed level of post-migration investment, greater investments in language skills imply less investment in other forms of human capital. Yet those with a lower discount rate or a higher level of ability may invest more in all kinds of post-migration human capital. Moreover, if there is complementarity in the labor market between language and other postmigration investments, immigrants who invest more in one form may invest more in both forms of human capital. ${ }^{2}$

As a result, it is hypothesized that among immigrants greater proficiency in the destination language enhances earnings and enhances the partial effect on earnings of schooling and pre-immigration labor market experience. The effect of greater investments in destination language skills on the partial effect of post-immigration experience is, however, ambiguous. It depends on whether the "expansion effect" (greater investment in all types of post-migration human capital) exceeds the "substitution effect" (substitution among sub-types for a given amount of post-migration investment).

\section{DATA}

This study uses the data from the 1991 Census of Canada, Public Use Micrcodata File (Individuals), 3 percent sample of the population. The Microdata file released from the Census contains information on knowledge of the official languages (English and French),

\footnotetext{
2 This is analogous to the observation that those who invest in more schooling also appear to make greater investments in on-the-job training.
} 
knowledge of unofficial languages, the language usually used at home, and mother tongue. ${ }^{3}$ The information on knowledge of the official languages and home language is used to construct the language proficiency explanatory variables that are the focus of the analysis. Information on mother tongue is used to construct several exogenous variables that serve as identifying instruments in some models (see Appendix A).

The Census information on earnings, educational attainment, labor market experience, duration of residence and place of residence is quite standard. The description of these variables is contained in Appendix A. Appendix Table B-1 provides the means and standard deviations of the dependent and explanatory variables.

Table 1 reports data on the distribution of adult male immigrants across the three language groups. These data are for the sample of foreign-born males from non-English speaking countries between the ages of 25 and 64 . Ideally the sample should be restricted to immigrants from both non-English speaking and non-French speaking countries since the objective is to ascertain the effect of linguistic adjustment on earnings. However, the birthplace categories used in the Public Use Sample released from the 1991 Census of Canada do not permit identification of any French-speaking countries. ${ }^{4}$ There are, in any case, very few immigrants in Canada from developed French-speaking countries (France and Belgium). Aged males and females of all ages are excluded from the analysis at this stage to avoid the problems inherent in modeling labor supply decisions.

According to the data in Table 1, about 5 percent of immigrants from non-English speaking countries do not speak either English or French. 47 percent of immigrants speak English and/or French but usually speak a non-official language at home. In other words, almost one-half of male immigrants from non-English speaking countries in Canada have an incomplete shift towards the official languages of Canada. 49 percent of

3 For an analysis of these language questions and recommendations for improvements, see Chiswick and Miller (1998).

4 While information on mother tongue could be used in place of country of origin, it would result in a non-random sample which, given the focus of the study, could result in considerable bias to the estimates. 
male immigrants from non-English speaking countries, however, speak English and/or French and usually speak one or both of these languages at home. The data in Table 1 are also presented separately for Quebec and English Canada (other than for the Atlantic Provinces). ${ }^{5}$ At this highly aggregated level of analysis, there is little difference between these two regions.

Table 2 reports the mean earnings of the three language categories for those who worked in Canada during 1990. There is a clear hierarchy in terms of earnings for the language categories. Immigrants who cannot conduct a conversation in an official language (L1) earn the least. Immigrants who can conduct a conversation in an official language but usually use a non-official language at home (L2) occupy an intermediate position. Those who can conduct a conversation in an official language and usually use an official language at home (L3) earn the most. These differences are large and statistically significant. ${ }^{6}$

5 Only limited information is available on a number of key variables for individuals from the Atlantic provinces. Since less than one percent of the sample resides in the Atlantic provinces, estimations that exclude the Atlantic provinces will not be prone to significant sample selection bias problems.

6 The percent differences between the earnings of the group who can conduct a conversation in an official language and usually speak an official language at home (L3) and the other two groups and associated ' $t$ ' statistics are:

\begin{tabular}{|c|c|c|c|}
\hline Language Group & $\begin{array}{c}\text { Total } \\
\text { Canada }\end{array}$ & $\begin{array}{l}\text { English } \\
\text { Canada }\end{array}$ & Quebec \\
\hline $\begin{array}{l}\text { Can conduct a conversation in an official } \\
\text { language but usually speaks a non-official } \\
\text { language at home (L2) }\end{array}$ & $\begin{array}{l}-34.45 \\
(21.87)\end{array}$ & $\begin{array}{l}-32.95 \\
(19.49)\end{array}$ & $\begin{array}{l}-42.60 \\
(10.05)\end{array}$ \\
\hline $\begin{array}{l}\text { Cannot conduct a conversation in an official } \\
\text { language (L1) }\end{array}$ & $\begin{array}{l}-69.98 \\
(16.14)\end{array}$ & $\begin{array}{r}-72.10 \\
(15.40)\end{array}$ & $\begin{array}{l}-57.89 \\
(5.59)\end{array}$ \\
\hline
\end{tabular}




\section{LANGUAGE PRACTICE AND EARNINGS}

The relationship between language skills and earnings is generally assessed using a human capital earnings function. ${ }^{7}$ This methodology is employed here. Specifically, the natural logarithm of annual earnings is assumed to be determined by the individual's educational attainment, labor market experience, weeks worked, province and region of residence, birthplace, duration in the destination, citizenship status and language proficiency. The language variables are based on those reported in Table 1. The possibility that the non-random nature of these language groups may result in biased estimates of the parameters of the wage function is taken in account using the generalization of Heckman's (1979) sample-selectivity correction proposed by Lee (1983). In this model, the lambda correction term computed for inclusion in the earnings function is constructed from estimates of a multinomial logit model of language practice. The specification of the language equation is developed in Chiswick and Miller (2000a). ${ }^{8}$

Estimates of the earnings equation obtained when the data are pooled across language groups are listed in Table 3. These estimates, obtained using Ordinary Least Squares (OLS), show that much of the earnings differentials apparent in Table 2 are due to differences across the language groups in human capital endowments (other than language) and weeks worked. The first three columns of Table 3 report the results for all of Canada, while columns (iv) and (v) report the results for English Canada and Quebec, respectively.

The results in Table 3, column (i) are for a conventional specification of the human capital earnings function that does not include the language variables. There are several notable features of these results. First, the increment in earnings associated with an additional year of education for immigrants is 3.8 percent. This is lower than the 5.2 percent

\footnotetext{
${ }^{7}$ For studies of the effect of language on earnings among the native born or foreign born in Canada, see, for example, Meng (1987), Abbott and Beach (1987), Chiswick and Miller (1988, 1992), Shapiro and Stelcner (1997), and Pendakur and Pendakur (1999). For a recent study for the U.S., see Chiswick and Miller (2000 b).

8 The identifying variables include the minority language concentration measure, linguistic distance and miles of the origin county from Canada. The refugee and colony
} 
for the native born, but it is comparable to the 3.9 percent for the foreign born reported from analysis of the 1981 Census of Canada (see Chiswick and Miller, 1988, 1992).

Second, the returns to labor market experience vary according to whether the experience was acquired pre- or post-migration. As duration of residence in Canada is a variable in the model, the returns to pre-migration experience are given by the coefficients on the experience variable, $\partial L N E A R N / \partial E X P=0.018-0.0007$ (EXP). Evaluated at $\mathrm{EXP}=10$ this equals 1.1 percent. The coefficients on the duration of residence variables record the differential returns to Canadian labor market experience over experience acquired abroad. This premium is $\partial L N E A R N / \partial P E R=0.036$ 0.00102(PER). Evaluated at $\mathrm{PER}=10$, this equals 2.6 percent. The sum of the coefficients on total experience and duration of residence give the earnings increase associated with being a year older and living an extra year in Canada, other variables the same. At $\mathrm{EXP}=\mathrm{PER}=10$, the partial effect on earnings of an extra year in Canada is 3.7 percent.

Third, citizenship is associated with 7 percent higher earnings. Citizenship was associated with a similar increment in earnings in the 1981 Census of Canada (see Chiswick and Miller, 1992).

Fourth, the elasticity of earnings with respect to weeks worked is only 0.96 . In other words, a one percent increase in weeks worked is associated with an increase in earnings of around 0.96 percent. A test of whether this coefficient is equal to unity gives a tstatistic of 1.76, which is statistically significant at about the 8 percent level. This elasticity measure is about five percentage points lower than the 1.01 reported in the study of the 1981 Census (see Chiswick and Miller (1992). ${ }^{9}$ Thus, in both years the elasticity is very close to unity.

variables are not identifying variables as they are transformations of the country of birth dichotomous variables.

9 Note that Chiswick and Miller (1992) include immigrants from English-speaking countries in their sample. The comparison between 1981 and 1991 of the coefficients on the weeks worked variable is made on the basis of estimation of equations using the 1991 Census data that include immigrants from English-speaking countries. 
Fifth, there are considerable differences in the mean earnings, ceteris paribus, across the provinces. Compared with immigrants in Ontario, immigrants living in Quebec have 23 percent lower earnings, those in the Prairie Provinces have 17 percent lower earnings, and immigrants resident in British Columbia have 10 percent lower earnings. In addition, residents of the major cities (Central Metropolitan Areas) have earnings about 11 percent higher than immigrants living outside of these areas.

The estimating equation is augmented by two language variables in Table 3, column (ii). The addition of these variables has only minor effects on the estimated impacts of the other variables. The results show that individuals who cannot conduct a conversation in an official language of Canada (L1) have a statistically significant 13 percent lower earnings $(' t$ ' $=2.96)$ than the benchmark group of individuals who can speak an official language and usually speak an official language at home (L3). Individuals who can speak an official language but usually speak a non-official language at home (L3) have earnings 11 percent lower (' $t$ ' = 7.11) than the benchmark group. There is no information in the Census of Canada on the degree of fluency among those who can speak an official language. The 11 percent earnings disadvantage could be capturing lesser official language fluency among those who continue to speak a nonofficial language at home. Or it could be measuring non-language effects on earnings that are related to the speaking of a non-official language at home (e.g., ethnicity), that is, an omitted variable that is correlated with not speaking an official language at home. To some extent the latter effect may be held constant through inclusion in the equation of country of birth variables.

Fourteen birthplace dummy variables are added to the model in Table 3, column (iii), with Italy as the benchmark. As a group, the country variables they are highly significant. The majority of the individual coefficients are statistically significant and a large number are associated with sizeable earnings differentials. The rank ordering of earnings by birthplace, ceteris paribus, from the lowest to the highest is: China, Middle East, Other Asia, Central and South America, Philippines, South Asia, Vietnam, Poland, Africa, Other Europe, (Italy, as the benchmark group), Portugal. Only immigrants from 
Germany, USSR and Hong Kong are shown to have earnings that are not significantly different from the earnings of Italian immigrants.

The addition of the birthplace variables (which control for dimensions of ethnic origin) is associated with a slight reduction in the earnings disadvantage associated with the two language variables, but these language variables remain highly significant. Earnings in the two language groups are lower than for those who speak an official language at home by about 10 percent. This change in the specification is also associated with a reduction to around 1.9 percentage points in the premium to Canadian labor market experience over pre-immigration experience, when evaluated at 10 years in Canada.

Columns (iv) and (v) in Table 3 report results separately for English Canada and Quebec. Only the model that includes the birthplace variables is reported. The results for English Canada in column (iv) are similar to those for all Canada (English Canada represents 83 percent of the total sample). In particular, the two language variables are associated with statistically significant 14 percent (L1) and 10 percent (L2) earnings disadvantages, respectively.

The findings for Quebec are slightly different from those for English Canada. The returns to education are 1.5 percentage points higher in Quebec (5.3 percent) than in English Canada (3.8 percent). The variable for whether the immigrant can speak an official language but usually speaks a non-official language at home is associated with a 14 percent earnings penalty. This effect is highly significant. The variable for immigrants who cannot conduct a conversation in an official language, however, is not statistically significant. The proportion of the sample in the latter group (2.7 percent) is less than in English Canada (4.1 percent), and the sample size is quite small. The differences in the language effects on earnings in English Canada and Quebec may be a reflection of sample-selection bias. This issue is addressed next. 
Table 4 presents results for earnings equations estimated for each of the three language states separately. Both OLS and selectivity-corrected estimates are presented. The data indicate selectivity bias only in the equation for individuals who can converse in an official language but who usually speak a non-official language at home. The lambda term has been constructed to be positive in each equation. ${ }^{10}$ Hence the positive coefficient on lambda for language state L2 indicates positive selection into that state. Individuals who can converse in an official language but elect to use a non-official language at home have a higher mean earnings in that language state than would a random sample of immigrants. That is, this group of immigrants has a comparative advantage in this language state. ${ }^{11}$

There are a number of striking patterns in the other coefficients in Table 4. The increments in earnings associated with additional years of education are 5.0 percent among immigrants who can conduct a conversation in an official language and who usually use an official language at home (L3), and 3.3 percent (selectivity-corrected estimate) among immigrants who can conduct a conversation in an official language but who usually use a non-official language at home (L2). Earnings are not related to the level of education among the relatively small group of immigrants who cannot conduct a conversation in an official language (L1). ${ }^{12}$ This pattern suggests a complementarity

\footnotetext{
10 The multinominal logit equations used to construct the lambda terms are reported in Appendix Table B-2.

11 Estimates of the effect of language on earnings were also obtained using an IV approach. The minority language concentration and linguistic distance variables and their squared terms were used as identifying instruments. The coefficient in the earnings equation on L1 was $-0.423(' \mathrm{t}$ ' $=0.53$ ) and that on L2 was $-0.264(' \mathrm{t}$ ' $=2.31$ ), Estimated impacts obtained by IV that are around three times the OLS estimates are also found for other countries (see Chiswick and Miller 1995, Dustman and van Soest 1997).

12 These differences are statistically significant. In the OLS equations, the coefficients of L3 and L2 differ by 1.3 percentage points, which has a t-ratio of 2.68 , while the coefficients of L3 and L1 differ by 6.9 percentage points which has a t-ratio of 5.59 .
} 
between official language fluency and educational attainment among immigrants in the Canadian labor market. ${ }^{13}$

The pattern of the impact on earnings of pre-immigration experience for the three language groups is similar to that of educational attainment. The gains are greater for language group L3 than for either of the other two groups. Evaluated at EXP=10, the gains in earnings for an extra year of experience for language groups L3, L2 and L1 are, respectively, 2.0 percent, 0.9 percent, and a statistically insignificant 0.1 percent. ${ }^{14}$ As a form of human capital, experience acquired abroad can be more profitably transformed into higher earnings where the immigrant has shifted fully to the use of an official language in everyday life in Canada. Where an immigrant cannot conduct a conversation in an official language, pre-immigration experience, like educational attainment, is not associated with higher earnings.

In contrast, the premium to post-immigration experience is greater for immigrants with lesser fluency in an official language. Among immigrants who cannot conduct a conversation in an official language (L1) the increment in earnings with duration in Canada is around 2.3 percent, evaluated at 10 years of duration in Canada, but for the L2 group it is 2.1 percent and for the L3 group 1.2 percent. An extra year of experience in Canada does more for enhancing earnings among those with the poorest language skills. This suggests a substitution of one form of "post-immigration" human capital for another in the labor market. The earnings increments for pre-immigration experience can be

13 Schaafsma and Sweetman (1999) also find that the effect of schooling on earnings among immigrants in Canada is greater the greater is the Canadian-specific human capital, which in their study is measured by years of labor market experience in Canada, controlling for foreign experience and year of arrival in Canada, among other variables.

14 There is a significant difference in the effects of experience in two of the language states. In the OLS analysis, the F-ratio for the difference in the experience variables for L3 versus $\mathrm{L} 2$ is $\mathrm{F}=4.15$ which is significant at the 1.6 percent level. For the effects of experience in L3 versus L1, F=1.629, which is not statistically significant (significant at the 19 percent level). This is presumably due to the statistical insignificance of the experience variables in L1 (high standard errors) which prevent the difference from L3 being estimated with precision. 
added to the premiums for Canadian labor market experience to estimate the combined effects. The total returns to Canadian labor market experience, i.e. an extra year older in Canada, for each language group are found to be around 3 percent, in particular, 2.4 percent for L1, 3.0 percent for L2 and 3.2 percent for L3.

While there are other interesting findings in Table 4, only one further result will be discussed here, the coefficient on the log of weeks worked variable. This is much higher (1.01), and not significantly different from unity, for immigrants who usually speak an official language at home (L3) than for the other language groups. This suggests that the weekly rate of pay for immigrants in the L3 language category does not vary with the number of weeks worked. For the other two groups, however, the weekly rate of pay tends to decline with weeks worked; coefficient of 0.91 for L2 and 0.92 for L1. This would be expected where part-year work attracted a premium, such as employment in seasonally sensitive industries or occupations. This could be a consequence of greater seasonality in employment among those with less proficiency in the official languages.

Tables 5 and 6 repeat the analysis for adult male immigrants who completed their education prior to immigrating to Canada. These individuals are defined as those for whom age at immigration exceeds their number of years of schooling plus six years. If there is an ambiguity because of the interval nature of the period of arrival variable, the respondent was not included in the analysis. This procedure assumes that schooling was continuous without interruption from age 6 until it was completed. ${ }^{15}$

The basic patterns that emerge for this sample of men who completed their schooling prior to immigration (71 percent of the total) is somewhat different from what was found for all immigrants (Table 5). The effect of schooling on earnings is smaller in this group (3.4 percent compared to 4.2 percent, when country of origin is held constant),

\footnotetext{
15 See Appendix Table B-3 for the means and standard deviations of the variables used in this analysis and Appendix Table B-4 for the multinominal logit model used to construct the lambda terms for inclusion in the selectivity corrected estimates in Table 6.
} 
but it is still highly significant. The effect on earnings of pre-immigration labor market experience is lower. Duration of residence in Canada, on the other hand, has a larger effect (2.6 percent evaluated at PER $=10$ when country of birth is held constant in Table 5, column iii). The earnings differentials among the language groups are larger. Compared to those who use the official language at home (L3), the L2 speakers have 12 percent lower earnings and the L1 speakers have 14 percent lower earnings when country of birth is held constant.

When the analyses are performed separately by language group, as with the full sample, only the L2 speakers show sample selectivity (Table 6). The effect of schooling on earnings increases with proficiency: 4.6 percent for L3, 2.5 percent for L2 and the effect is small and not significant for L1. The effect of labor market experience prior to immigration is significant only for L2, and is 0.5 percent for L2 at EXP $=10$. The effect of duration in Canada is significant for all three groups. Evaluated at PER $=10$, the effects of duration in the selectivity corrected analysis vary by little across the language groups, 2.8 percent for L3, 2.3 percent for L2 and 2.6 percent for L1.

Thus, using a simple algorithm, among those who completed their schooling prior to immigrating to Canada, educational attainment and language skills appear to be complements, those with greater language skills have a larger effect of schooling on earnings. Pre-immigration labor market experience (i.e., total experience when duration is held constant) has a weak effect on immigrant earnings. There is no systematic pattern for post-immigration experience with respect to language practice, although the effect is larger than in the full sample and highly significant (about 2.3 to 2.8 percent per year evaluated at PER $=10$ ).

\section{SUMMARY AND CONCLUSION}

This study shows that language skills are a key determinant of earnings among immigrants in Canada. Immigrants who cannot conduct a conversation in an official language and those who, while being able to conduct a conversation in an official language, usually speak a non-official language at home, have earnings around 10 to 12 percent lower 
than immigrants who usually speak an official language at home, when other variables are the same. The earnings gap is larger, 12 to 14 percent, among those who completed their schooling prior to immigrating. There is evidence of positive selection into the group that can conduct a conversation in an official language but who usually speak a non-official language at home.

The increment in earnings associated with an additional year of education is 5 percent among immigrants who usually speak an official language at home (L3), around 3 percent for those who can conduct a conversation in an official language who usually speak a non-official language at home (L2), and zero for immigrants who cannot conduct a conversation in an official language (L1). When evaluated at 10 years, the impact of preimmigration experience for these three groups is around 2 percent, 1 percent and zero, respectively, while the impact of duration of residence in Canada for the three groups is around 1 percent, 2 percent and 2.5 percent, respectively.

The analysis in this study is consistent with the hypothesis that greater proficiency in an official language enhances earnings in the Canadian labor market and enhances the effects on earnings of schooling and possibly pre-immigration labor market experience (complementarity in production), but that it can be a substitute in generating earnings for other Canadian-specific labor market experience. Thus, immigrants who lack proficiency in the official languages of Canada have lower earnings because of two effects: the direct effect of lower proficiency and an indirect effect through the smaller returns from schooling and pre-immigration experience.

The analysis of immigrant earnings presented in this paper has implications for immigration policy and absorption policy. An immigration policy that screens immigrants, in part, by their official language skills would result in higher earnings among the foreign born. An immigrant absorption policy that promotes investments in official language skills after migration and using these skills in the labor market and at home can enhance the value of the skills immigrants bring with them and hence the economic well-being of immigrants. 


\section{REFERENCES}

Abbott, Michael G. and Charles M. Beach (1987). "Immigrant Earnings Differentials and Cohort Effects in Canada", Institute for Economic Research, Queen's University, Discussion paper No. 705.

Chiswick, Barry R. and Paul W. Miller (1988). "Earnings in Canada: The Roles of Immigrant Generation, French Ethnicity and Language", in T. Paul Schultz (ed.) Research in Population Economics, Vol. 6, Greenwich, Connecticut: JAI Press Inc., pp. 183-228.

Chiswick, Barry R. and Paul W. Miller (1992). "Language in the Immigrant Labor Market", in Barry R. Chiswick (ed.), Immigration, Language and Ethnic Issues: Canada and the United States, American Enterprise Institute, Washington, D.C., pp. 229-296.

Chiswick, Barry R. and Paul W. Miller (1995). "The Endogeneity Between Language and Earnings: International Analyses", Journal of Labor Economics, Vol.13, No.2, pp.246-288.

Chiswick, Barry R. and Paul W. Miller (1998). "Census Language Questions in North America," Journal of Economic and Social Measurement, Vol.25, pp. 73-95.

Chiswick, Barry R. and Paul W. Miller (2000a). "A Model of Destination Language Acquisition: Application to Male Immigrants in Canada," Research on Immigration and Integration in the Metropolis, Working Paper \#00-13, September, Vancouver, British Columbia.

Chiswick, Barry R. and Paul W. Miller (2000b). "Immigrant Earnings: Language Skills, Linguistic Concentrations and the Business Cycle", Xerox, University of Illinois at Chicago.

Dustmann, Christian and Arthur van Soest (1997). "Language and Earnings: A Panel Data Analysis", paper presented to the CEPR Conference on European Migration: What Do We Know?, Munich, November 14/15, 1997.

Heckman, James J. (1979). "Sample Selection Bias as a Specification Error", Econometrica, Vol. 47, pp.153-162.

Lee, Lung-Fei (1983). "Generalized Econometric Models with Selectivity", Econometrica, Vol. 51, pp.507-512.

Meng, Ronald (1987). "The Earnings of Canadian Immigrant and Native-born Males", Applied Economics, Vol. 19, No. 8, pp.1107-1119.

Pendakur, Krishna and Ravi Pendakur (1999). "Speaking in Tongues: Language as Human Capital and Ethnicity." Paper presented at the Conference on Immigration with an International Perspective, Vancouver, January 1999. 
Schaafsma, Joseph and Arthur Sweetman (1999). "Immigrant Earnings: Age at Immigration Matters." Paper presented at the Conference on Immigration with an International Perspective, Vancouver, January 1999.

Shapiro, Daniel M., and Morton Stelcner (1997). "Language and Earnings in Quebec: Trends over Twenty Years, 1970-1990", Canadian Public Policy/Analyse de Politiques, Vol.23, No.2, pp.115-140.

Statistics Canada (1994). User Documentation for Public Use Microdata File on Individuals, 1991 Census of Canada, Ottawa: Statistics Canada, Service Number 48039E. 


\section{Table 1}

\section{Language Categories of Male Immigrants From Non-English Speaking Countries, Age 25-64, 1991 Census of Canada \\ (Percent)}

\begin{tabular}{lccc}
\hline Language State & Total Sample & English Canada $^{(\mathrm{a})}$ & Quebec $^{\text {Speaks Neither English nor French (L1) }}$ \\
\hline $\begin{array}{l}\text { Speaks English and/or French AND: } \\
\text { - Usually speaks a Non-Official }\end{array}$ & 4.8 & 5.0 & 3.5 \\
$\quad \begin{array}{l}\text { Language at Home (L2) } \\
\text { - Usually spe aks an Official Language }\end{array}$ & 46.6 & 46.4 & 48.5 \\
$\quad$ at Home (L3) & 48.7 & 48.6 & 48.0 \\
\hline Total $^{(\mathrm{b})}$ & 100.0 & 100.0 & 100.0 \\
\hline
\end{tabular}

(a) English Canada does not include the Atlantic Provinces.

(b) Columns may not sum to 100.0 due to rounding.

Source: 1991 Census of Canada, Public Use Microdata File (Individuals

Table 2

Mean Earnings by Language Categories of Male Immigrants From Non-English Speaking Countries, Age 25-64, 1991 Census of Canada (Percent)

\begin{tabular}{lccc}
\hline Language State & Total Sample & English Canada $^{(\text {a) }}$ & Quebec \\
\hline $\begin{array}{l}\text { Speaks Neither English nor French (L1) } \\
\text { Speaks English and/or French AND: }\end{array}$ & 20,278 & 20,757 & 16,661 \\
$\begin{array}{l}\text { - Usually speaks a Non-Official } \\
\quad \text { Language at Home (L2) }\end{array}$ & & & \\
$\quad$ - Usually speaks an Official Language & 27,860 & 28,566 & 24,077 \\
$\quad$ at Home (L3) & 37,352 & 37,831 & 34,938 \\
\hline
\end{tabular}

(a) English Canada does not include the Atlantic Provinces.

Source: 1991 Census of Canada, Public Use Microdata File (Individuals). 
Table 3

Estimates of Earnings Equation, Male Immigrants Aged 25-64, Canada (Dependent Variable: Natural Logarithm of Annual Earnings)

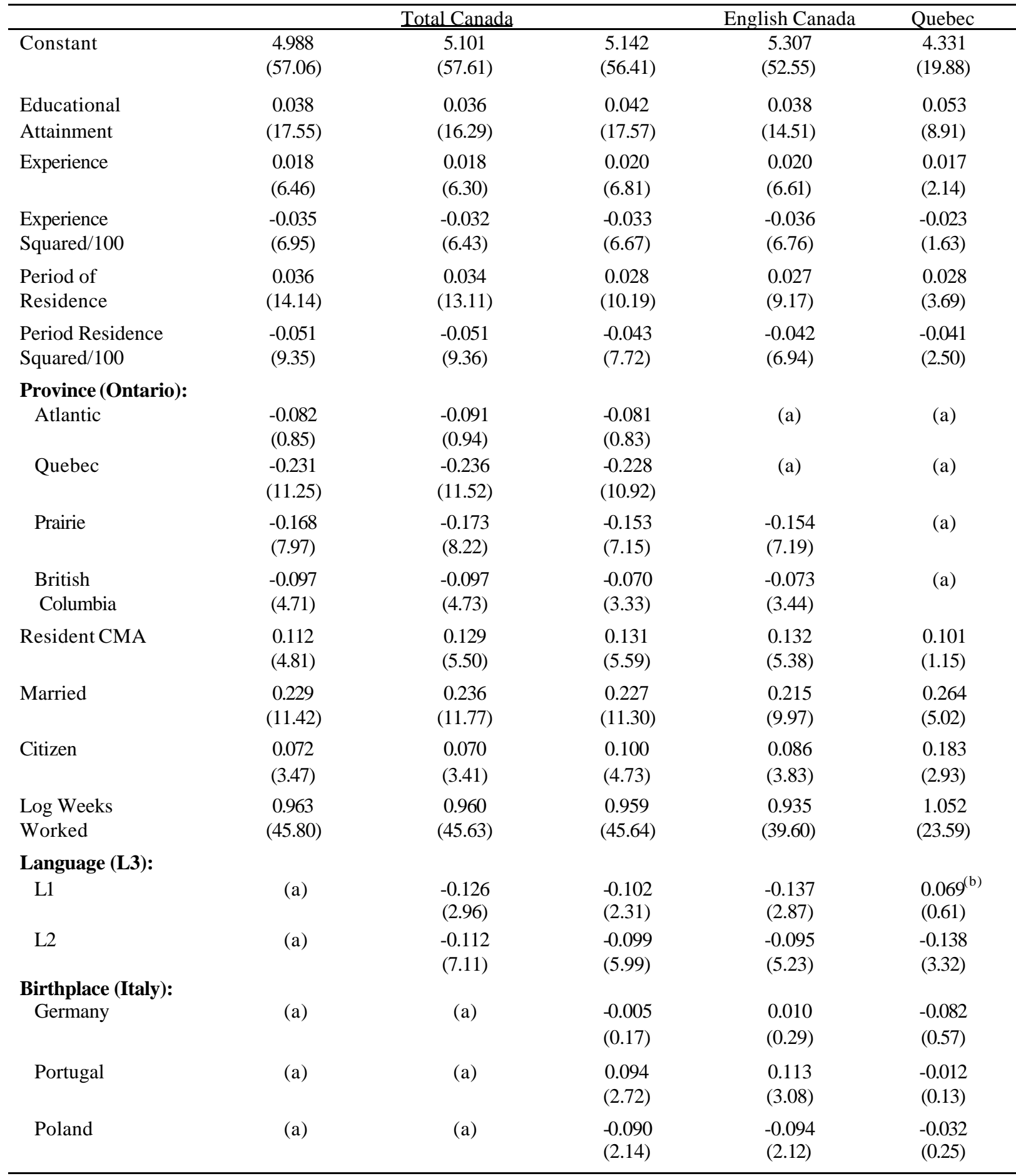




\begin{tabular}{|c|c|c|c|c|c|}
\hline USSR & (a) & (a) & $\begin{array}{l}-0.021 \\
(0.33)\end{array}$ & $\begin{array}{c}-0.038 \\
(0.56)\end{array}$ & $\begin{array}{l}0.386 \\
(3.39)\end{array}$ \\
\hline $\begin{array}{l}\text { Other } \\
\text { Europe }\end{array}$ & (a) & (a) & $\begin{array}{l}-0.071 \\
(2.91)\end{array}$ & $\begin{array}{l}-0.067 \\
(2.46)\end{array}$ & $\begin{array}{c}-0.071 \\
(1.27)\end{array}$ \\
\hline Middle East & (a) & (a) & $\begin{array}{r}-0.253 \\
(5.47)\end{array}$ & $\begin{array}{l}-0.280 \\
(5.23)\end{array}$ & $\begin{array}{r}-0.154 \\
(1.61)\end{array}$ \\
\hline South Asia & (a) & (a) & $\begin{array}{r}-0.133 \\
(3.94)\end{array}$ & $\begin{array}{l}-0.117 \\
(3.26)\end{array}$ & $\begin{array}{r}-0.289 \\
(2.44)\end{array}$ \\
\hline Hong Kong & (a) & (a) & $\begin{array}{l}-0.040 \\
(1.00)\end{array}$ & $\begin{array}{l}-0.037 \\
(0.87)\end{array}$ & $\begin{array}{c}-0.062 \\
(0.26)\end{array}$ \\
\hline China & (a) & (a) & $\begin{array}{r}-0.288 \\
(7.19)\end{array}$ & $\begin{array}{l}-0.269 \\
(6.37)\end{array}$ & $\begin{array}{l}-0.422 \\
(3.00)\end{array}$ \\
\hline Philippines & (a) & (a) & $\begin{array}{l}-0.166 \\
(4.03)\end{array}$ & $\begin{array}{l}-0.173 \\
(4.00)\end{array}$ & $\begin{array}{l}0.107 \\
(0.80)\end{array}$ \\
\hline Vietnam & (a) & (a) & $\begin{array}{l}-0.125 \\
(2.77)\end{array}$ & $\begin{array}{l}-0.131 \\
(2.62)\end{array}$ & $\begin{array}{l}-0.136 \\
(1.23)\end{array}$ \\
\hline Other Asia & (a) & (a) & $\begin{array}{l}-0.206 \\
(4.47)\end{array}$ & $\begin{array}{l}-0.205 \\
(4.10)\end{array}$ & $\begin{array}{r}-0.141 \\
(1.17)\end{array}$ \\
\hline Africa & (a) & (a) & $\begin{array}{l}-0.085 \\
(2.35)\end{array}$ & $\begin{array}{l}-0.102 \\
(2.46)\end{array}$ & $\begin{array}{r}-0.050 \\
(0.66)\end{array}$ \\
\hline $\begin{array}{l}\text { C. \& S. } \\
\text { America }\end{array}$ & (a) & (a) & $\begin{array}{l}-0.171 \\
(4.60)\end{array}$ & $\begin{array}{l}-0.128 \\
(3.01)\end{array}$ & $\begin{array}{c}-0.217 \\
(2.76)\end{array}$ \\
\hline Sample Size & 27,976 & 27,976 & 27,976 & 23,272 & $4, \overline{518}$ \\
\hline $\bar{R}^{2}$ & 0.2099 & 0.2112 & 0.2146 & 0.2028 & 0.2560 \\
\hline F Statistic & 572.63 & 500.45 & 264.54 & 220.23 & 63.17 \\
\hline Mean Dep.Var. & 9.949 & 9.949 & 9.949 & 9.983 & 9.771 \\
\hline
\end{tabular}

(a) = variable not entered.

(b) = estimate of the coefficient of L1 in Quebec is based on 121 cases.

' $t$ ' statistics in parentheses corrected for heteroskedasticity.

Source: 1991 Census of Canada, Public Use Microdata File (Individuals) 
Table 4

Estimates of Earnings Equation by Language Practice, Male Immigrants Aged 25-64, Canada (Dependent Variable: Natural Logarithm of Annual Earnings)

\begin{tabular}{|c|c|c|c|c|c|c|}
\hline \multirow[b]{3}{*}{ Variable } & \multicolumn{2}{|c|}{ Language State L $3^{(\mathrm{a})}$} & \multicolumn{2}{|c|}{ Language State L2 ${ }^{\text {(a) }}$} & \multicolumn{2}{|c|}{ Language State $\mathrm{L1}^{(\mathrm{a})}$} \\
\hline & & Selectivity & & Selectivity & & Selectivity \\
\hline & OLS & Corrected & OLS & Corrected & OLS & Corrected \\
\hline Constant & $\begin{array}{c}4.755 \\
(34.78)\end{array}$ & $\begin{array}{c}4.758 \\
(30.49)\end{array}$ & $\begin{array}{c}5.346 \\
(41.45)\end{array}$ & $\begin{array}{c}5.246 \\
(46.08)\end{array}$ & $\begin{array}{c}5.960 \\
(12.40)\end{array}$ & $\begin{array}{c}6.111 \\
(11.30)\end{array}$ \\
\hline $\begin{array}{l}\text { Educational } \\
\text { Attainment }\end{array}$ & $\begin{array}{c}0.050 \\
(14.45)\end{array}$ & $\begin{array}{c}0.050 \\
(12.01)\end{array}$ & $\begin{array}{c}0.037 \\
(11.14)\end{array}$ & $\begin{array}{l}0.033 \\
(9.20)\end{array}$ & $\begin{array}{l}-0.019 \\
(1.60)\end{array}$ & $\begin{array}{l}-0.008 \\
(0.27)\end{array}$ \\
\hline Experience & $\begin{array}{l}0.030 \\
(7.14)\end{array}$ & $\begin{array}{l}0.030 \\
(7.10)\end{array}$ & $\begin{array}{l}0.013 \\
(3.01)\end{array}$ & $\begin{array}{l}0.014 \\
(3.38)\end{array}$ & $\begin{array}{l}0.013 \\
(0.83)\end{array}$ & $\begin{array}{l}0.009 \\
(0.51)\end{array}$ \\
\hline $\begin{array}{l}\text { Experience } \\
\text { Squared/100 }\end{array}$ & $\begin{array}{l}-0.051 \\
(6.81)\end{array}$ & $\begin{array}{l}-0.051 \\
(7.35)\end{array}$ & $\begin{array}{l}-0.024 \\
(3.19)\end{array}$ & $\begin{array}{l}-0.024 \\
(3.33)\end{array}$ & $\begin{array}{l}-0.036 \\
(1.61)\end{array}$ & $\begin{array}{l}-0.035 \\
(1.49)\end{array}$ \\
\hline $\begin{array}{l}\text { Period of } \\
\text { Residence (PER) }\end{array}$ & $\begin{array}{l}0.017 \\
(4.39)\end{array}$ & $\begin{array}{l}0.017 \\
(3.74)\end{array}$ & $\begin{array}{l}0.033 \\
(8.06)\end{array}$ & $\begin{array}{l}0.032 \\
(7.72)\end{array}$ & $\begin{array}{l}0.031 \\
(2.19)\end{array}$ & $\begin{array}{l}0.033 \\
(2.19)\end{array}$ \\
\hline PER Squared/100 & $\begin{array}{l}-0.023 \\
(3.03)\end{array}$ & $\begin{array}{l}-0.023 \\
(3.11)\end{array}$ & $\begin{array}{l}-0.053 \\
(5.50)\end{array}$ & $\begin{array}{l}-0.057 \\
(5.88)\end{array}$ & $\begin{array}{l}-0.057 \\
(1.54)\end{array}$ & $\begin{array}{l}-0.051 \\
(1.28)\end{array}$ \\
\hline $\begin{array}{l}\text { Province (Ontario): } \\
\text { Atlantic }\end{array}$ & $\begin{array}{l}-0.077 \\
(0.79)\end{array}$ & $\begin{array}{l}-0.077 \\
(0.82)\end{array}$ & $\begin{array}{l}0.036 \\
(0.14)\end{array}$ & $\begin{array}{l}-0.004 \\
(0.02)\end{array}$ & (b) & (b) \\
\hline Quebec & $\begin{array}{l}-0.181 \\
(6.35)\end{array}$ & $\begin{array}{l}-0.181 \\
(6.50)\end{array}$ & $\begin{array}{l}-0.302 \\
(9.49)\end{array}$ & $\begin{array}{l}-0.305 \\
(10.11)\end{array}$ & $\begin{array}{l}-0.052 \\
(0.46)\end{array}$ & $\begin{array}{l}-0.018 \\
(0.12)\end{array}$ \\
\hline Prairie & $\begin{array}{l}-0.107 \\
(3.75)\end{array}$ & $\begin{array}{l}-0.107 \\
(3.58)\end{array}$ & $\begin{array}{l}-0.213 \\
(6.30)\end{array}$ & $\begin{array}{l}-0.231 \\
(6.69)\end{array}$ & $\begin{array}{l}-0.035 \\
(0.33)\end{array}$ & $\begin{array}{r}-0.020 \\
(0.16)\end{array}$ \\
\hline British Columbia & $\begin{array}{l}-0.058 \\
(2.04)\end{array}$ & $\begin{array}{l}-0.058 \\
(2.02)\end{array}$ & $\begin{array}{l}-0.071 \\
(2.18)\end{array}$ & $\begin{array}{l}-0.083 \\
(2.59)\end{array}$ & $\begin{array}{l}-0.124 \\
(1.06)\end{array}$ & $\begin{array}{r}-0.132 \\
(1.09)\end{array}$ \\
\hline Lives in CMA & $\begin{array}{l}0.120 \\
(4.38)\end{array}$ & $\begin{array}{l}0.121 \\
(4.13)\end{array}$ & $\begin{array}{l}0.128 \\
(2.77)\end{array}$ & $\begin{array}{l}0.166 \\
(3.84)\end{array}$ & $\begin{array}{l}0.141 \\
(0.76)\end{array}$ & $\begin{array}{l}0.102 \\
(0.54)\end{array}$ \\
\hline Married & $\begin{array}{l}0.222 \\
(8.55)\end{array}$ & $\begin{array}{l}0.223 \\
(8.59)\end{array}$ & $\begin{array}{l}0.225 \\
(6.86)\end{array}$ & $\begin{array}{l}0.247 \\
(7.67)\end{array}$ & $\begin{array}{l}0.356 \\
(2.92)\end{array}$ & $\begin{array}{l}0.365 \\
(3.13)\end{array}$ \\
\hline Citizen & $\begin{array}{l}0.132 \\
(4.11)\end{array}$ & $\begin{array}{l}0.132 \\
(4.33)\end{array}$ & $\begin{array}{l}0.082 \\
(2.80)\end{array}$ & $\begin{array}{l}0.081 \\
(2.87)\end{array}$ & $\begin{array}{l}0.022 \\
(0.22)\end{array}$ & $\begin{array}{l}0.069 \\
(0.48)\end{array}$ \\
\hline Log Weeks Worked & $\begin{array}{c}1.012 \\
(31.97)\end{array}$ & $\begin{array}{c}1.012 \\
(43.03)\end{array}$ & $\begin{array}{c}0.919 \\
(31.64)\end{array}$ & $\begin{array}{c}0.911 \\
(43.62)\end{array}$ & $\begin{array}{c}0.909 \\
(10.08)\end{array}$ & $\begin{array}{c}0.917 \\
(13.37)\end{array}$ \\
\hline $\begin{array}{l}\text { Birthplace (Italy): } \\
\text { Germany }\end{array}$ & $\begin{array}{l}0.019 \\
(0.50)\end{array}$ & $\begin{array}{l}0.019 \\
(0.48)\end{array}$ & $\begin{array}{l}0.024 \\
(0.34)\end{array}$ & $\begin{array}{l}0.024 \\
(0.29)\end{array}$ & (b) & (b) \\
\hline Portugal & $\begin{array}{l}0.053 \\
(1.05)\end{array}$ & $\begin{array}{l}0.053 \\
(0.98)\end{array}$ & $\begin{array}{l}0.073 \\
(1.42)\end{array}$ & $\begin{array}{l}0.060 \\
(1.16)\end{array}$ & $\begin{array}{l}-0.075 \\
(0.51)\end{array}$ & $\begin{array}{l}-0.057 \\
(0.36)\end{array}$ \\
\hline Poland & $\begin{array}{l}-0.094 \\
(1.48)\end{array}$ & $\begin{array}{l}-0.094 \\
(1.55)\end{array}$ & $\begin{array}{l}-0.077 \\
(1.27)\end{array}$ & $\begin{array}{l}-0.058 \\
(0.96)\end{array}$ & $\begin{array}{l}-0.317 \\
(1.29)\end{array}$ & $\begin{array}{l}-0.304 \\
(1.35)\end{array}$ \\
\hline USSR & $\begin{array}{l}-0.063 \\
(0.67)\end{array}$ & $\begin{array}{l}-0.062 \\
(0.71)\end{array}$ & $\begin{array}{l}0.035 \\
(0.40)\end{array}$ & $\begin{array}{l}0.082 \\
(0.81)\end{array}$ & $\begin{array}{l}-0.091 \\
(0.37)\end{array}$ & $\begin{array}{l}-0.124 \\
(0.25)\end{array}$ \\
\hline Other Europe & $\begin{array}{l}-0.043 \\
(1.38)\end{array}$ & $\begin{array}{l}-0.043 \\
(1.37)\end{array}$ & $\begin{array}{c}-0.083 \\
(1.98)\end{array}$ & $\begin{array}{l}-0.080 \\
(1.90)\end{array}$ & $\begin{array}{l}-0.541 \\
(2.29)\end{array}$ & $\begin{array}{l}-0.527 \\
(2.70)\end{array}$ \\
\hline
\end{tabular}




\begin{tabular}{|c|c|c|c|c|c|c|}
\hline Middle East & $\begin{array}{l}-0.154 \\
(2.34)\end{array}$ & $\begin{array}{l}-0.154 \\
(2.53)\end{array}$ & $\begin{array}{l}-0.309 \\
(4.62)\end{array}$ & $\begin{array}{l}-0.281 \\
(4.63)\end{array}$ & $\begin{array}{l}-0.837 \\
(2.29)\end{array}$ & $\begin{array}{l}-0.837 \\
(2.87)\end{array}$ \\
\hline South Asia & $\begin{array}{l}-0.069 \\
(1.48)\end{array}$ & $\begin{array}{l}-0.069 \\
(1.38)\end{array}$ & $\begin{array}{l}-0.202 \\
(3.95)\end{array}$ & $\begin{array}{l}-0.177 \\
(3.50)\end{array}$ & $\begin{array}{l}-0.222 \\
(1.17)\end{array}$ & $\begin{array}{l}-0.154 \\
(0.58)\end{array}$ \\
\hline Hong Kong & $\begin{array}{l}0.003 \\
(0.05)\end{array}$ & $\begin{array}{l}0.005 \\
(0.05)\end{array}$ & $\begin{array}{l}-0.066 \\
(1.21)\end{array}$ & $\begin{array}{l}0.016 \\
(0.26)\end{array}$ & $\begin{array}{l}-0.587 \\
(1.43)\end{array}$ & $\begin{array}{r}-0.572 \\
(1.90)\end{array}$ \\
\hline China & $\begin{array}{l}-0.068 \\
(0.90)\end{array}$ & $\begin{array}{l}-0.067 \\
(0.71)\end{array}$ & $\begin{array}{l}-0.361 \\
(6.57)\end{array}$ & $\begin{array}{l}-0.299 \\
(5.15)\end{array}$ & $\begin{array}{l}-0.333 \\
(2.28)\end{array}$ & $\begin{array}{l}-0.370 \\
(1.96)\end{array}$ \\
\hline Philippines & $\begin{array}{l}-0.098 \\
(1.54)\end{array}$ & $\begin{array}{l}-0.097 \\
(1.40)\end{array}$ & $\begin{array}{l}-0.213 \\
(3.68)\end{array}$ & $\begin{array}{l}-0.201 \\
(3.15)\end{array}$ & $\begin{array}{l}-0.395 \\
(2.04)\end{array}$ & $\begin{array}{r}-0.317 \\
(0.43)\end{array}$ \\
\hline Vietnam & $\begin{array}{r}-0.071 \\
(0.64)\end{array}$ & $\begin{array}{c}-0.070 \\
(0.54)\end{array}$ & $\begin{array}{c}-0.153 \\
(2.61)\end{array}$ & $\begin{array}{c}-0.082 \\
(1.28)\end{array}$ & $\begin{array}{r}-0.238 \\
(1.25)\end{array}$ & $\begin{array}{r}-0.254 \\
(1.26)\end{array}$ \\
\hline Other Asia & $\begin{array}{c}-0.055 \\
(0.79)\end{array}$ & $\begin{array}{r}-0.054 \\
(0.68)\end{array}$ & $\begin{array}{c}-0.276 \\
(4.32)\end{array}$ & $\begin{array}{c}-0.223 \\
(3.61)\end{array}$ & $\begin{array}{c}-0.504 \\
(1.94)\end{array}$ & $\begin{array}{l}-0.520 \\
(2.15)\end{array}$ \\
\hline Africa & $\begin{array}{l}-0.023 \\
(0.52)\end{array}$ & $\begin{array}{l}-0.023 \\
(0.52)\end{array}$ & $\begin{array}{l}-0.219 \\
(3.44)\end{array}$ & $\begin{array}{l}-0.193 \\
(2.99)\end{array}$ & $\begin{array}{l}-1.536 \\
(8.03)\end{array}$ & $\begin{array}{l}-1.455 \\
(1.64)\end{array}$ \\
\hline C. \& S. America & $\begin{array}{l}-0.147 \\
(2.80)\end{array}$ & $\begin{array}{l}-0.147 \\
(2.65)\end{array}$ & $\begin{array}{l}-0.193 \\
(3.42)\end{array}$ & $\begin{array}{l}-0.175 \\
(3.05)\end{array}$ & $\begin{array}{l}-0.256 \\
(1.34)\end{array}$ & $\begin{array}{l}-0.246 \\
(1.13)\end{array}$ \\
\hline Lambda & (b) & $\begin{array}{l}-0.002 \\
(0.03) \\
-\end{array}$ & (b) & $\begin{array}{r}0.167 \\
(2.89) \\
-\end{array}$ & (b) & $\begin{array}{r}-0.130 \\
(0.43)\end{array}$ \\
\hline $\bar{R}^{2}$ & 0.1853 & 0.1852 & 0.2110 & 0.2115 & 0.2225 & 0.2219 \\
\hline Sample Size & 14,177 & 14,177 & 12,720 & 12,720 & 1,079 & 1,079 \\
\hline $\begin{array}{l}\text { F Statistic } \\
\text { Mean Dep. Var. }\end{array}$ & $\begin{array}{l}120.42 \\
10.133\end{array}$ & $\begin{array}{l}116.11 \\
10.133\end{array}$ & $\begin{array}{c}126.97 \\
9.788\end{array}$ & $\begin{array}{r}122.81 \\
9.788\end{array}$ & $\begin{array}{l}13.34 \\
9.433\end{array}$ & $\begin{array}{l}12.82 \\
9.433\end{array}$ \\
\hline
\end{tabular}

Note: ' $\mathrm{t}$ ' statistics for OLS corrected for heteroskedasticity; selectivity-corrected estimates computed from Lee (1983).

(a): L1 = Speaks neither English nor French; L2 = Speaks an Official language but usually speaks a nonofficial language at home; L3 = Speaks an Official language and usually speaks an official language at home.

(b): variable not entered.

Source: 1991 Census of Canada, Public Use Microdata File (Individuals) 
Table 5

Estimates of Earnings Equation, Male Immigrants Aged 25-64 who Completed

Their Education Overseas, Canada

(Dependent Variable: Natural Logarithm of Annual Earnings)

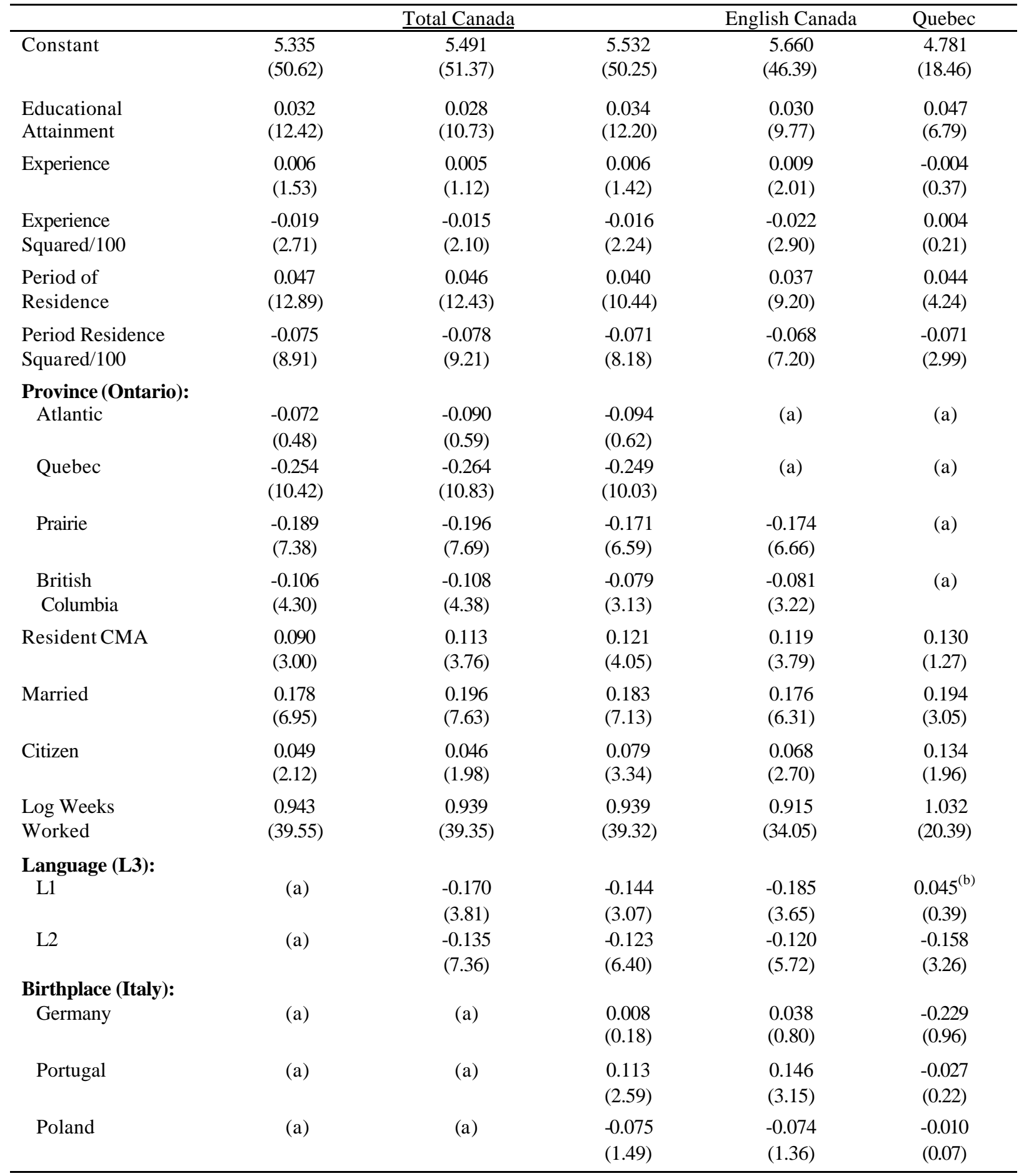




\begin{tabular}{|c|c|c|c|c|c|}
\hline USSR & (a) & (a) & $\begin{array}{l}0.013 \\
(0.17)\end{array}$ & $\begin{array}{c}-0.002 \\
(0.02)\end{array}$ & $\begin{array}{l}0.573 \\
(3.74)\end{array}$ \\
\hline $\begin{array}{l}\text { Other } \\
\text { Europe }\end{array}$ & (a) & (a) & $\begin{array}{l}-0.070 \\
(2.15)\end{array}$ & $\begin{array}{l}-0.075 \\
(2.01)\end{array}$ & $\begin{array}{c}-0.023 \\
(0.34)\end{array}$ \\
\hline Middle East & (a) & (a) & $\begin{array}{l}-0.304 \\
(5.54)\end{array}$ & $\begin{array}{l}-0.314 \\
(4.93)\end{array}$ & $\begin{array}{l}-0.237 \\
(2.12)\end{array}$ \\
\hline South Asia & (a) & (a) & $\begin{array}{r}-0.134 \\
(3.27)\end{array}$ & $\begin{array}{l}-0.104 \\
(2.38)\end{array}$ & $\begin{array}{l}-0.375 \\
(2.65)\end{array}$ \\
\hline Hong Kong & (a) & (a) & $\begin{array}{l}-0.035 \\
(0.69)\end{array}$ & $\begin{array}{l}-0.021 \\
(0.40)\end{array}$ & $\begin{array}{r}-0.177 \\
(0.50)\end{array}$ \\
\hline China & (a) & (a) & $\begin{array}{l}-0.316 \\
(6.46)\end{array}$ & $\begin{array}{l}-0.293 \\
(5.59)\end{array}$ & $\begin{array}{l}-0.422 \\
(2.79)\end{array}$ \\
\hline Philippines & (a) & (a) & $\begin{array}{l}-0.172 \\
(3.51)\end{array}$ & $\begin{array}{l}-0.170 \\
(3.27)\end{array}$ & $\begin{array}{l}0.076 \\
(0.50)\end{array}$ \\
\hline Vietnam & (a) & (a) & $\begin{array}{r}-0.162 \\
(3.11)\end{array}$ & $\begin{array}{l}-0.147 \\
(2.60)\end{array}$ & $\begin{array}{l}-0.241 \\
(1.76)\end{array}$ \\
\hline Other Asia & (a) & (a) & $\begin{array}{l}-0.249 \\
(4.56)\end{array}$ & $\begin{array}{l}-0.256 \\
(4.24)\end{array}$ & $\begin{array}{r}-0.114 \\
(0.87)\end{array}$ \\
\hline Africa & (a) & (a) & $\begin{array}{l}-0.125 \\
(2.73)\end{array}$ & $\begin{array}{l}-0.114 \\
(2.22)\end{array}$ & $\begin{array}{c}-0.143 \\
(1.47)\end{array}$ \\
\hline $\begin{array}{l}\text { C. \& S. } \\
\text { America }\end{array}$ & (a) & (a) & $\begin{array}{l}-0.168 \\
(3.72)\end{array}$ & $\begin{array}{l}-0.111 \\
(2.14)\end{array}$ & $\begin{array}{c}-0.228 \\
(2.43)\end{array}$ \\
\hline Sample Size & 19,894 & 19,894 & 19,894 & 16,452 & 3,340 \\
\hline $\bar{R}^{2}$ & 0.2026 & 0.2047 & 0.2093 & 0.1974 & 0.2520 \\
\hline F Statistic & 389.88 & 342.37 & 182.58 & 150.89 & 46.00 \\
\hline Mean Dep.Var. & 9.859 & 9.859 & 9.859 & 9.897 & 9.673 \\
\hline
\end{tabular}

(a) = variable not entered.

(b) = estimate of the coefficient of L1 in Quebec is based on 121 cases.

' $t$ ' statistics in parentheses corrected for heteroskedasticity.

Source: 1991 Census of Canada, Public Use Microdata File (Individuals) 
Table 6

Estimates of Earnings Equation by Language Practice, Male Immigrants Aged 25-64 who Completed Their Education Overseas, Canada (Dependent Variable: Natural Logarithm of Annual Earnings)

\begin{tabular}{|c|c|c|c|c|c|c|}
\hline \multirow[b]{2}{*}{ Variable } & \multicolumn{2}{|c|}{ Language State L $3^{(\mathrm{a})}$} & \multicolumn{2}{|c|}{ Language State L2 ${ }^{(a)}$} & \multicolumn{2}{|c|}{ Language State $\mathrm{L}^{(\mathrm{a})}$} \\
\hline & OLS & $\begin{array}{l}\text { Selectivity } \\
\text { Corrected }\end{array}$ & OLS & $\begin{array}{l}\text { Selectivity } \\
\text { Corrected }\end{array}$ & OLS & $\begin{array}{l}\text { Selectivity } \\
\text { Corrected }\end{array}$ \\
\hline Constant & $\begin{array}{l}5.354 \\
(28.51)\end{array}$ & $\begin{array}{c}5.247 \\
(22.52)\end{array}$ & $\begin{array}{c}5.471 \\
(38.71)\end{array}$ & $\begin{array}{c}5.335 \\
(42.33)\end{array}$ & $\begin{array}{c}5.967 \\
(12.02)\end{array}$ & $\begin{array}{c}6.217 \\
(11.21)\end{array}$ \\
\hline $\begin{array}{l}\text { Educational } \\
\text { Attainment }\end{array}$ & $\begin{array}{l}0.042 \\
(9.12)\end{array}$ & $\begin{array}{l}0.046 \\
(6.53)\end{array}$ & $\begin{array}{l}0.032 \\
(8.82)\end{array}$ & $\begin{array}{l}0.025 \\
(6.21)\end{array}$ & $\begin{array}{l}-0.019 \\
(1.61)\end{array}$ & $\begin{array}{l}-0.001 \\
(0.03)\end{array}$ \\
\hline Experience & $\begin{array}{l}-0.001 \\
(0.09)\end{array}$ & $\begin{array}{l}-0.002 \\
(0.23)\end{array}$ & $\begin{array}{l}0.010 \\
(1.88)\end{array}$ & $\begin{array}{l}0.009 \\
(1.80)\end{array}$ & $\begin{array}{l}0.013 \\
(0.79)\end{array}$ & $\begin{array}{l}0.007 \\
(0.36)\end{array}$ \\
\hline $\begin{array}{l}\text { Experience } \\
\text { Squared/100 }\end{array}$ & $\begin{array}{l}-0.009 \\
(0.65)\end{array}$ & $\begin{array}{l}-0.008 \\
(0.65)\end{array}$ & $\begin{array}{l}-0.023 \\
(2.46)\end{array}$ & $\begin{array}{l}-0.022 \\
(2.49)\end{array}$ & $\begin{array}{l}-0.035 \\
(1.50)\end{array}$ & $\begin{array}{r}-0.033 \\
(1.39)\end{array}$ \\
\hline $\begin{array}{l}\text { Period of } \\
\text { Residence (PER) }\end{array}$ & $\begin{array}{l}0.038 \\
(5.63)\end{array}$ & $\begin{array}{l}0.041 \\
(5.76)\end{array}$ & $\begin{array}{l}0.038 \\
(7.47)\end{array}$ & $\begin{array}{l}0.036 \\
(7.34)\end{array}$ & $\begin{array}{l}0.032 \\
(2.19)\end{array}$ & $\begin{array}{l}0.037 \\
(2.34)\end{array}$ \\
\hline PER Squared/100 & $\begin{array}{l}-0.066 \\
(4.35)\end{array}$ & $\begin{array}{l}-0.066 \\
(4.91)\end{array}$ & $\begin{array}{l}-0.061 \\
(4.98)\end{array}$ & $\begin{array}{l}-0.065 \\
(5.45)\end{array}$ & $\begin{array}{l}-0.066 \\
(1.64)\end{array}$ & $\begin{array}{l}-0.055 \\
(1.30)\end{array}$ \\
\hline $\begin{array}{l}\text { Province (Ontario): } \\
\text { Atlantic }\end{array}$ & $\begin{array}{l}-0.078 \\
(0.48)\end{array}$ & $\begin{array}{l}-0.071 \\
(0.51)\end{array}$ & $\begin{array}{l}0.012 \\
(0.04)\end{array}$ & $\begin{array}{l}-0.066 \\
(0.30)\end{array}$ & (b) & (b) \\
\hline Quebec & $\begin{array}{l}-0.197 \\
(5.32)\end{array}$ & $\begin{array}{l}-0.192 \\
(5.04)\end{array}$ & $\begin{array}{l}-0.311 \\
(8.92)\end{array}$ & $\begin{array}{c}-0.323 \\
(9.81)\end{array}$ & $\begin{array}{l}-0.042 \\
(0.36)\end{array}$ & $\begin{array}{l}0.014 \\
(0.10)\end{array}$ \\
\hline Prairie & $\begin{array}{l}-0.134 \\
(3.40)\end{array}$ & $\begin{array}{l}-0.124 \\
(2.97)\end{array}$ & $\begin{array}{l}-0.208 \\
(5.69)\end{array}$ & $\begin{array}{l}-0.240 \\
(6.40)\end{array}$ & $\begin{array}{l}-0.035 \\
(0.33)\end{array}$ & $\begin{array}{r}-0.012 \\
(0.09)\end{array}$ \\
\hline British Columbia & $\begin{array}{l}-0.080 \\
(2.09)\end{array}$ & $\begin{array}{l}-0.073 \\
(1.82)\end{array}$ & $\begin{array}{l}-0.063 \\
(1.81)\end{array}$ & $\begin{array}{l}-0.088 \\
(2.49)\end{array}$ & $\begin{array}{l}-0.125 \\
(1.05)\end{array}$ & $\begin{array}{r}-0.137 \\
(1.12)\end{array}$ \\
\hline Lives in CM A & $\begin{array}{l}0.112 \\
(2.89)\end{array}$ & $\begin{array}{l}0.097 \\
(2.23)\end{array}$ & $\begin{array}{l}0.109 \\
(2.22)\end{array}$ & $\begin{array}{l}0.172 \\
(3.66)\end{array}$ & $\begin{array}{l}0.151 \\
(0.80)\end{array}$ & $\begin{array}{l}0.088 \\
(0.46)\end{array}$ \\
\hline Married & $\begin{array}{l}0.133 \\
(3.76)\end{array}$ & $\begin{array}{l}0.117 \\
(2.69)\end{array}$ & $\begin{array}{l}0.207 \\
(5.33)\end{array}$ & $\begin{array}{l}0.271 \\
(6.83)\end{array}$ & $\begin{array}{l}0.353 \\
(2.83)\end{array}$ & $\begin{array}{l}0.371 \\
(3.10)\end{array}$ \\
\hline Citizen & $\begin{array}{l}0.120 \\
(3.02)\end{array}$ & $\begin{array}{l}0.124 \\
(3.24)\end{array}$ & $\begin{array}{l}0.064 \\
(2.04)\end{array}$ & $\begin{array}{l}0.065 \\
(2.16)\end{array}$ & $\begin{array}{l}0.016 \\
(0.16)\end{array}$ & $\begin{array}{l}0.093 \\
(0.63)\end{array}$ \\
\hline Log Weeks Worked & $\begin{array}{c}0.978 \\
(23.67)\end{array}$ & $\begin{array}{c}0.984 \\
(31.06)\end{array}$ & $\begin{array}{c}0.919 \\
(30.16)\end{array}$ & $\begin{array}{c}0.904 \\
(40.30)\end{array}$ & $\begin{array}{l}0.906 \\
(9.77)\end{array}$ & $\begin{array}{c}0.919 \\
(13.15)\end{array}$ \\
\hline $\begin{array}{l}\text { Birthplace (Italy): } \\
\text { Germany }\end{array}$ & $\begin{array}{l}0.067 \\
(1.10)\end{array}$ & $\begin{array}{l}0.063 \\
(1.04)\end{array}$ & $\begin{array}{l}0.009 \\
(0.13)\end{array}$ & $\begin{array}{l}0.006 \\
(0.07)\end{array}$ & (b) & (b) \\
\hline Portugal & $\begin{array}{l}0.071 \\
(0.83)\end{array}$ & $\begin{array}{l}0.073 \\
(0.86)\end{array}$ & $\begin{array}{l}0.100 \\
(1.78)\end{array}$ & $\begin{array}{l}0.085 \\
(1.50)\end{array}$ & $\begin{array}{l}-0.090 \\
(0.59)\end{array}$ & $\begin{array}{l}-0.058 \\
(0.36)\end{array}$ \\
\hline Poland & $\begin{array}{l}-0.042 \\
(0.48)\end{array}$ & $\begin{array}{l}-0.047 \\
(0.53)\end{array}$ & $\begin{array}{l}-0.063 \\
(0.96)\end{array}$ & $\begin{array}{l}-0.038 \\
(0.59)\end{array}$ & $\begin{array}{l}-0.330 \\
(1.31)\end{array}$ & $\begin{array}{l}-0.308 \\
(1.34)\end{array}$ \\
\hline USSR & $\begin{array}{l}0.078 \\
(0.68)\end{array}$ & $\begin{array}{l}0.045 \\
(0.32)\end{array}$ & $\begin{array}{l}-0.008 \\
(0.07)\end{array}$ & $\begin{array}{l}0.071 \\
(0.62)\end{array}$ & $\begin{array}{l}-0.103 \\
(0.41)\end{array}$ & $\begin{array}{l}-0.157 \\
(0.32)\end{array}$ \\
\hline Other Europe & $\begin{array}{l}-0.022 \\
(0.44)\end{array}$ & $\begin{array}{l}-0.020 \\
(0.41)\end{array}$ & $\begin{array}{l}-0.058 \\
(1.26)\end{array}$ & $\begin{array}{l}-0.056 \\
(1.22)\end{array}$ & $\begin{array}{l}-0.602 \\
(2.43)\end{array}$ & $\begin{array}{l}-0.579 \\
(2.88)\end{array}$ \\
\hline
\end{tabular}




\begin{tabular}{|c|c|c|c|c|c|c|}
\hline Middle East & $\begin{array}{l}-0.205 \\
(2.42)\end{array}$ & $\begin{array}{l}-0.218 \\
(2.69)\end{array}$ & $\begin{array}{l}-0.319 \\
(4.31)\end{array}$ & $\begin{array}{l}-0.280 \\
(4.24)\end{array}$ & $\begin{array}{l}-0.852 \\
(2.31)\end{array}$ & $\begin{array}{l}-0.850 \\
(2.89)\end{array}$ \\
\hline South Asia & $\begin{array}{l}-0.024 \\
(0.39)\end{array}$ & $\begin{array}{l}-0.029 \\
(0.43)\end{array}$ & $\begin{array}{l}-0.189 \\
(3.34)\end{array}$ & $\begin{array}{l}-0.156 \\
(2.82)\end{array}$ & $\begin{array}{l}-0.238 \\
(1.23)\end{array}$ & $\begin{array}{l}-0.126 \\
(0.46)\end{array}$ \\
\hline Hong Kong & $\begin{array}{l}-0.001 \\
(0.01)\end{array}$ & $\begin{array}{l}-0.048 \\
(0.34)\end{array}$ & $\begin{array}{l}-0.039 \\
(0.63)\end{array}$ & $\begin{array}{l}0.088 \\
(1.23)\end{array}$ & $\begin{array}{l}-0.568 \\
(1.27)\end{array}$ & $\begin{array}{r}-0.539 \\
(1.71)\end{array}$ \\
\hline China & $\begin{array}{l}-0.038 \\
(0.33)\end{array}$ & $\begin{array}{l}-0.083 \\
(0.58)\end{array}$ & $\begin{array}{l}-0.388 \\
(6.16)\end{array}$ & $\begin{array}{l}-0.296 \\
(4.62)\end{array}$ & $\begin{array}{l}-0.345 \\
(2.28)\end{array}$ & $\begin{array}{l}-0.405 \\
(2.11)\end{array}$ \\
\hline Philippines & $\begin{array}{l}-0.087 \\
(1.04)\end{array}$ & $\begin{array}{l}-0.089 \\
(1.00)\end{array}$ & $\begin{array}{l}-0.197 \\
(3.10)\end{array}$ & $\begin{array}{l}-0.186 \\
(2.70)\end{array}$ & $\begin{array}{l}-0.421 \\
(2.09)\end{array}$ & $\begin{array}{l}-0.291 \\
(0.39)\end{array}$ \\
\hline Vietnam & $\begin{array}{l}-0.167 \\
(1.12)\end{array}$ & $\begin{array}{c}-0.206 \\
(1.29)\end{array}$ & $\begin{array}{r}-0.159 \\
(2.47)\end{array}$ & $\begin{array}{c}-0.056 \\
(0.79)\end{array}$ & $\begin{array}{r}-0.251 \\
(1.30)\end{array}$ & $\begin{array}{c}-0.278 \\
(1.35)\end{array}$ \\
\hline Other Asia & $\begin{array}{l}-0.102 \\
(1.06)\end{array}$ & $\begin{array}{c}-0.140 \\
(1.28)\end{array}$ & $\begin{array}{r}-0.284 \\
(4.08)\end{array}$ & $\begin{array}{l}-0.206 \\
(3.07)\end{array}$ & $\begin{array}{r}-0.517 \\
(1.98)\end{array}$ & $\begin{array}{r}-0.542 \\
(2.21)\end{array}$ \\
\hline Africa & $\begin{array}{l}-0.031 \\
(0.49)\end{array}$ & $\begin{array}{l}-0.033 \\
(0.53)\end{array}$ & $\begin{array}{l}-0.230 \\
(3.25)\end{array}$ & $\begin{array}{l}-0.199 \\
(2.84)\end{array}$ & $\begin{array}{l}-1.549 \\
(7.89)\end{array}$ & $\begin{array}{l}-1.416 \\
(1.59)\end{array}$ \\
\hline C. \& S. America & $\begin{array}{l}-0.122 \\
(1.68)\end{array}$ & $\begin{array}{l}-0.131 \\
(1.72)\end{array}$ & $\begin{array}{l}-0.174 \\
(2.84)\end{array}$ & $\begin{array}{l}-0.142 \\
(2.27)\end{array}$ & $\begin{array}{l}-0.279 \\
(1.41)\end{array}$ & $\begin{array}{l}-0.257 \\
(1.15)\end{array}$ \\
\hline Lambda & (b) & $\begin{array}{r}0.066 \\
(0.62) \\
-\end{array}$ & (b) & $\begin{array}{r}0.299 \\
(4.22) \\
-\end{array}$ & (b) & $\begin{array}{r}-0.215 \\
(0.68)\end{array}$ \\
\hline $\bar{R}^{2}$ & 0.1739 & 0.1739 & 0.2109 & 0.2121 & 0.2192 & 0.2188 \\
\hline Sample Size & 7,912 & 7,912 & 10,919 & 10,919 & 1,063 & 1,063 \\
\hline $\begin{array}{l}\text { F Statistic } \\
\text { Mean Dep. Var. }\end{array}$ & $\begin{array}{c}62.70 \\
10.057\end{array}$ & $\begin{array}{r}60.47 \\
10.057\end{array}$ & $\begin{array}{c}109.07 \\
9.758\end{array}$ & $\begin{array}{r}105.97 \\
9.758\end{array}$ & $\begin{array}{l}12.93 \\
9.428\end{array}$ & $\begin{array}{l}12.44 \\
9.428\end{array}$ \\
\hline
\end{tabular}

Note: 't' statistics for OLS corrected for heteroskedasticity; selectivity-corrected estimates computed from Lee (1983).

(a): L1 = Speaks neither English nor French; L2 = Speaks an Official language but usually speaks a nonofficial language at home; L3 = Speaks an Official language and usually speaks an official language at home.

(b): variable not entered.

Source: 1991 Census of Canada, Public Use Microdata File (Individuals) 


\section{APPENDIX A}

\section{Definitions}

Definition of Population: Foreign-born men from non-English speaking countries, aged twenty-five to sixty-four who worked at least one week in 1990. Non-permanent residents (i.e., persons on a student authorization, employment authorization, Minister's permit or a refugee claimant) are excluded from the analysis as the 1991 Census Public Use Microdata File (PUMF) does not contain information on the year of entry into Canada for this group. A small number of persons for whom data were not available on questions used in the construction of variables, and those resident in the Yukon and Northwest Territories, are also excluded from the analysis. Other sample exclusions are noted in the definitions. For further information on the data set, see Statistics Canada (1994).

Earnings (LNEARN): The natural logarithm of the sum of wage and salary income and self-employment income in 1990. Individuals reporting negative (self-employment loss) or zero earnings (voluntary work or "in kind" income) are assigned an earnings of $\$ 100$ (see Chiswick and Miller (1992)). The PUMF truncates the income data at upper and lower limits for confidentiality reasons. These limits vary by region. In the construction of the earnings variable, values of 1.5 times these limits are used. Around one-third of one percent of wage and salary records and two percent of self-employment income records are in the open-end intervals.

Language Practice (LANGTYPE): LANGTYPE is a trichotomous variable. The first category (L1) comprises individuals who cannot conduct a conversation in English or French. The second category (L2) comprises individuals who can conduct a conversation in English or French, but usually speak a non-official language at home. The third category (L3) comprises those who can conduct a conversation in English or French and usually use an official language at home.

Weeks Worked $(L N W W)$ : The natural logarithm of the number of weeks worked by the respondent in 1990.

Years of Education (EDUC): This variable records the total years of full-time education. It is constructed from the Census information on total years of schooling for respondents who do not possess a university qualification. For individuals who possess a university qualification, the following years of full-time equivalent schooling are added to the years of secondary schooling: Diploma below bachelor level (2.4 years); Bachelor's degree (three years for those reporting three or fewer years of university, four years for all others); Diploma above bachelor level (four years for those reporting four or fewer years of university, five years for all others); Degree in medicine, dentistry, etc. (seven years); Master's Degree (six years); earned doctorate (eight years).

Years Since Migration (YSM): The census information on year at arrival is presented in single years for some arrival cohorts, small intervals for some cohorts in the non-Atlantic 
provinces, and large intervals for the Atlantic provinces. A continuous measure was formed from this information by assigning midpoints to all arrival intervals, and subtracting this value from 1991. A quadratic specification is used. Individuals who arrived in Canada during 1991 are excluded from the study of earnings.

Birthplace (BIRTH): The following countries or regions of birth are distinguished in the census file for immigrants resident outside the Atlantic provinces (listed in order of numerical importance): United Kingdom; Other Europe; Central and South America and Caribbean; Italy; United States; Southern Asia (e.g., Bangladesh, India, Pakistan); Federal Republic of Germany; Africa; Poland; Middle East and Western Asia (e.g., Turkey, Iran, Lebanon, Saudi Arabia); Portugal; Other Eastern and South East Asia (e.g., Japan, South Korea, Singapore, Thailand); People's Republic of China; Hong Kong; Philippines; Vietnam; USSR; Other. For immigrants resident in the Atlantic Provinces, the only birthplace categories distinguished are: United States; United Kingdom; Other Europe; and Other. Immigrants from the United Kingdom, the United States and those from "Central America, Caribbean and Bermuda and South America" whose mother tongue is English are excluded from the analysis, given that study of language fluency is most appropriately focused on immigrants from non-English speaking backgrounds. In addition, the small number of immigrants from the residual "Other" birthplace region are excluded from the analysis, as a direct line distance can not be assigned to this group in the construction of the "MILES" variable (see below). Immigrants from Italy are used as the benchmark group.

Marital Status (MARRIED): This is a binary variable that is set equal to one for individuals who are married (includes common-law partners) and is defined to equal zero for all other marital states.

Location: Two location variables are used in the study. The first records province of residence. This information was grouped as follows: Atlantic Provinces (Newfoundland, Nova Scotia, New Brunswick, Prince Edward Island), Quebec, Ontario, Prairie Provinces (Manitoba, Saskatchewan, Alberta), and British Columbia. The second locality variable records the size of the place of residence. Individuals residing in Census Metropolitan Areas (defined as having a population of at least 100,000 based on the 1986 Census) are distinguished from other individuals.

Citizenship (CITIZEN): Individuals who hold Canadian citizenship are distinguished from immigrants who have not yet become citizens.

Minority Language Concentration (CONC); Linguistic Distance (LD); Refugee (REFUGEE); Colony (COLONY); Direct-Line Distances (MILES); for information on these instruments, see Chiswick and Miller (2000a). 


\section{Appendix B}

\section{Appendix Table B-1}

Means and Standard Deviations of Main Variables, Male Immigrants from Non-English Speaking Countries Aged 25-64, 1991 Census of Canada

\begin{tabular}{|c|c|c|c|c|c|c|}
\hline \multirow[t]{2}{*}{ Variable } & \multicolumn{2}{|c|}{ Total Sample } & \multicolumn{2}{|c|}{ English Canada $^{(\mathrm{a})}$} & \multicolumn{2}{|c|}{ Quebec } \\
\hline & Mean & St. Dev. & Mean & St. Dev. & Mean & St. Dev. \\
\hline Age & 43.53 & 10.47 & 43.52 & 10.50 & 43.50 & 10.31 \\
\hline Education Level & 11.78 & 4.11 & 11.77 & 4.02 & 11.76 & 4.55 \\
\hline Experience & 26.75 & 12.07 & 26.75 & 12.06 & 26.73 & 12.10 \\
\hline Period of Residence & 20.23 & 12.17 & 20.32 & 12.30 & 19.42 & 11.32 \\
\hline Atlantic Provinces & 0.007 & 0.08 & (b) & & (b) & \\
\hline Quebec & 0.162 & 0.37 & 0.000 & 0.00 & 1.000 & 0.00 \\
\hline Ontario & 0.548 & 0.50 & 0.659 & 0.47 & (b) & \\
\hline Prairie Provinces & 0.131 & 0.34 & 0.157 & 0.36 & (b) & \\
\hline British Columbia & 0.153 & 0.36 & 0.184 & 0.39 & (b) & \\
\hline Lives in CMA & 0.870 & 0.34 & 0.860 & 0.35 & 0.946 & 0.23 \\
\hline Married & 0.826 & 0.38 & 0.829 & 0.38 & 0.810 & 0.39 \\
\hline Citizen & 0.756 & 0.43 & 0.749 & 0.43 & 0.789 & 0.41 \\
\hline Weeks & 45.35 & 12.19 & 45.48 & 12.06 & 44.65 & 12.85 \\
\hline Income & 32,378 & 25,345 & 32,913 & 25,217 & 29,408 & 25,689 \\
\hline Log Income & 9.949 & 1.30 & 9.983 & 1.28 & 9.771 & 1.41 \\
\hline \multicolumn{7}{|l|}{ Miles Between } \\
\hline Canada $\&$ Origin $^{(\mathrm{c})}$ & 4988 & 1466 & 5041 & 1449 & 4661 & 1697 \\
\hline Linguistic Distance & 0.502 & 0.11 & 0.505 & 0.11 & 0.487 & 0.10 \\
\hline \multicolumn{7}{|l|}{ Minority Language } \\
\hline Concentration & 2.258 & 2.42 & 2.392 & 2.52 & 1.653 & 1.66 \\
\hline Refugee & 0.047 & 0.21 & 0.049 & 0.22 & 0.042 & 0.20 \\
\hline Colony & 0.257 & 0.44 & 0.271 & 0.44 & 0.195 & 0.40 \\
\hline Italy & 0.138 & 0.34 & 0.128 & 0.33 & 0.193 & 0.40 \\
\hline Germany & 0.063 & 0.24 & 0.071 & 0.26 & 0.024 & 0.15 \\
\hline Portugal & 0.060 & 0.24 & 0.061 & 0.24 & 0.054 & 0.23 \\
\hline Poland & 0.042 & 0.20 & 0.047 & 0.21 & 0.022 & 0.15 \\
\hline USSR & 0.014 & 0.12 & 0.015 & 0.12 & 0.005 & 0.07 \\
\hline Other Europe & 0.249 & 0.43 & 0.240 & 0.43 & 0.267 & 0.44 \\
\hline Middle East & 0.042 & 0.20 & 0.036 & 0.19 & 0.079 & 0.27 \\
\hline Southern Asia & 0.084 & 0.28 & 0.095 & 0.29 & 0.034 & 0.18 \\
\hline Hong Kong & 0.044 & 0.21 & 0.052 & 0.22 & 0.006 & 0.08 \\
\hline China & 0.047 & 0.21 & 0.052 & 0.22 & 0.020 & 0.14 \\
\hline Philippines & 0.033 & 0.18 & 0.038 & 0.19 & 0.005 & 0.07 \\
\hline Vietnam & 0.034 & 0.18 & 0.033 & 0.18 & 0.037 & 0.19 \\
\hline Other Asia & 0.039 & 0.19 & 0.040 & 0.20 & 0.033 & 0.18 \\
\hline Africa & 0.062 & 0.24 & 0.053 & 0.22 & 0.112 & 0.32 \\
\hline C. \& S. America & 0.050 & 0.22 & 0.040 & 0.20 & 0.106 & 0.31 \\
\hline Sample Size & \multicolumn{2}{|c|}{27,976} & \multicolumn{2}{|c|}{23,272} & \multicolumn{2}{|c|}{4,518} \\
\hline
\end{tabular}

(a) = Excludes the Atlantic Provinces. See text for explanation.

(b) = Variable not relevant.

(c) = Distance variable for Quebec defined with reference to Montreal; for the total sample and English Canada it is the smaller of the distance from Toronto and Vancouver..

Source: 1991 Census of Canada, Public Use Microdata File (Individuals) 
Appendix Table B-2

Reduced Form Multinomial Logit Model of Language Practice, Male Immigrants, 25-64, Canada, 1991 Census of Canada

\begin{tabular}{|c|c|c|}
\hline Variable & $\log (\mathrm{L} 2 / \mathrm{L} 1)$ & $\log (\mathrm{L} 3 / \mathrm{L} 1)$ \\
\hline Constant & $\begin{array}{l}1.645 \\
(4.63)\end{array}$ & $\begin{array}{l}2.153 \\
(5.66)\end{array}$ \\
\hline Age & $\begin{array}{c}-0.053 \\
(13.49)\end{array}$ & $\begin{array}{l}-0.097 \\
(22.98)\end{array}$ \\
\hline Educational Attainment & $\begin{array}{c}0.242 \\
(27.52)\end{array}$ & $\begin{array}{c}0.401 \\
(41.90)\end{array}$ \\
\hline Period of Residence (PER) & $\begin{array}{l}0.054 \\
(4.20)\end{array}$ & $\begin{array}{l}0.130 \\
(9.61)\end{array}$ \\
\hline PER Squared/100 & $\begin{array}{l}0.070 \\
(2.04)\end{array}$ & $\begin{array}{l}0.104 \\
(2.95)\end{array}$ \\
\hline Province (Ontario): & & \\
\hline Atlantic & $\begin{array}{l}0.208 \\
(0.20)\end{array}$ & $\begin{array}{l}0.551 \\
(0.54)\end{array}$ \\
\hline Quebec & $\begin{array}{r}0.450 \\
(4.00)\end{array}$ & $\begin{array}{l}0.580 \\
(4.98)\end{array}$ \\
\hline Prairie & $\begin{array}{l}0.057 \\
(0.50)\end{array}$ & $\begin{array}{l}0.414 \\
(3.42)\end{array}$ \\
\hline British Columbia & $\begin{array}{l}0.137 \\
(1.23)\end{array}$ & $\begin{array}{l}0.434 \\
(3.72)\end{array}$ \\
\hline Lives in CMA & $\begin{array}{l}-0.176 \\
(1.14)\end{array}$ & $\begin{array}{l}-0.752 \\
(4.78)\end{array}$ \\
\hline Married & $\begin{array}{l}0.215 \\
(2.08)\end{array}$ & $\begin{array}{l}-0.033 \\
(0.31)\end{array}$ \\
\hline Refugee & $\begin{array}{l}-1.067 \\
(7.44)\end{array}$ & $\begin{array}{l}-2.451 \\
(15.22)\end{array}$ \\
\hline Colony & $\begin{array}{l}1.032 \\
(6.70)\end{array}$ & $\begin{array}{l}0.778 \\
(4.76)\end{array}$ \\
\hline Minority Language & -0.115 & -0.203 \\
\hline Concentration & $(7.78)$ & (12.95) \\
\hline Linguistic Distance & $\begin{array}{l}-2.153 \\
(5.58)\end{array}$ & $\begin{array}{l}-7.688 \\
(18.60)\end{array}$ \\
\hline Miles Origin Country From & 0.038 & 0.171 \\
\hline Canada/1000 & $(0.81)$ & $(3.42)$ \\
\hline Log Weeks Worked & $\begin{array}{l}0.131 \\
(2.18)\end{array}$ & $\begin{array}{l}0.338 \\
(5.16)\end{array}$ \\
\hline Citizen & $\begin{array}{c}0.889 \\
(10.35)\end{array}$ & $\begin{array}{c}1.076 \\
(11.83)\end{array}$ \\
\hline $\begin{array}{l}\text { Sample Size } \\
\chi^{2}\end{array}$ & \multicolumn{2}{|c|}{27,976} \\
\hline Pseudo $\mathrm{R}^{2}$ & \multicolumn{2}{|c|}{0.2510} \\
\hline
\end{tabular}


Note: L1 = Speaks neither English nor French; L2 $=$ Speaks an Official Language but usually speaks a non-Official language at home; L3 = Speaks an Official language and usually speaks an Official language at home.

Asymptotic ' $\mathrm{t}$ ' statistics in parentheses.

Note: Birthplace variables are not included in the reduced form as the Refugee, Colony and Miles Origin Country from Canada variables are each linearly related to the birthplace variables, and the Minority Language Concentration and Linguistic Distance variables are constructed, in part, using information on birthplace.

Source: 1991 Census of Canada, Public Use Microdata File (individuals). 
Appendix Table B-3

Means and Standard Deviations of Main Variables, Male Immigrants from Non-English Speaking Countries, 25-64 who Completed Their Education Overseas, 1991 Census of Canada

\begin{tabular}{|c|c|c|c|c|c|c|}
\hline \multirow[t]{2}{*}{ Variable } & \multicolumn{2}{|c|}{ Total Sample } & \multicolumn{2}{|c|}{ English Canada $^{(\mathrm{a})}$} & \multicolumn{2}{|c|}{ Quebec } \\
\hline & Mean & St. Dev. & Mean & St. Dev. & Mean & St. Dev. \\
\hline Age & 45.44 & 10.43 & 45.43 & 10.46 & 45.43 & 10.27 \\
\hline Education Level & 11.14 & 4.22 & 11.17 & 4.15 & 10.96 & 4.56 \\
\hline Experience & 29.31 & 12.01 & 29.26 & 12.03 & 29.47 & 11.93 \\
\hline Period of Residence & 17.05 & 11.53 & 17.01 & 11.61 & 17.10 & 11.00 \\
\hline Atlantic Provinces & 0.005 & 0.07 & (b) & & (b) & \\
\hline Quebec & 0.168 & 0.37 & 0.000 & 0.00 & 1.000 & 0.00 \\
\hline Ontario & 0.541 & 0.50 & 0.654 & 0.48 & (b) & \\
\hline Prairie Provinces & 0.132 & 0.34 & 0.160 & 0.37 & (b) & \\
\hline British Columbia & 0.154 & 0.36 & 0.186 & 0.39 & (b) & \\
\hline Lives in CMA & 0.887 & 0.32 & 0.878 & 0.33 & 0.946 & 0.23 \\
\hline Married & 0.859 & 0.35 & 0.862 & 0.34 & 0.844 & 0.36 \\
\hline Citizen & 0.693 & 0.46 & 0.683 & 0.47 & 0.741 & 0.44 \\
\hline Weeks & 44.63 & 12.69 & 44.76 & 12.57 & 43.93 & 13.29 \\
\hline Income & 29,995 & 23,946 & 30,613 & 24,064 & 26,721 & 22,824 \\
\hline Log Income & 9.859 & 1.32 & 9.897 & 1.30 & 9.673 & 1.42 \\
\hline \multicolumn{7}{|l|}{ Miles Between } \\
\hline Canada \& Origin ${ }^{(\mathrm{c})}$ & 5077 & 1524 & 5153 & 1503 & 4669 & 1738 \\
\hline Linguistic Distance & 0.512 & 0.11 & 0.516 & 0.12 & 0.494 & 0.10 \\
\hline \multicolumn{7}{|l|}{ Minority Language } \\
\hline Concentration & 2.194 & 2.42 & 2.332 & 2.53 & 1.572 & 1.61 \\
\hline Refugee & 0.051 & 0.22 & 0.054 & 0.23 & 0.039 & 0.19 \\
\hline Colony & 0.284 & 0.45 & 0.303 & 0.46 & 0.196 & 0.40 \\
\hline Italy & 0.122 & 0.33 & 0.112 & 0.32 & 0.175 & 0.38 \\
\hline Germany & 0.048 & 0.21 & 0.055 & 0.23 & 0.016 & 0.13 \\
\hline Portugal & 0.061 & 0.24 & 0.063 & 0.24 & 0.057 & 0.23 \\
\hline Poland & 0.047 & 0.21 & 0.052 & 0.22 & 0.024 & 0.15 \\
\hline USSR & 0.011 & 0.11 & 0.013 & 0.11 & 0.003 & 0.05 \\
\hline Other Europe & 0.225 & 0.42 & 0.213 & 0.41 & 0.258 & 0.44 \\
\hline Middle East & 0.048 & 0.21 & 0.041 & 0.20 & 0.086 & 0.28 \\
\hline Southern Asia & 0.096 & 0.29 & 0.108 & 0.31 & 0.038 & 0.19 \\
\hline Hong Kong & 0.043 & 0.20 & 0.051 & 0.22 & 0.005 & 0.07 \\
\hline China & 0.053 & 0.22 & 0.059 & 0.24 & 0.024 & 0.15 \\
\hline Philippines & 0.038 & 0.19 & 0.045 & 0.21 & 0.006 & 0.08 \\
\hline Vietnam & 0.040 & 0.20 & 0.041 & 0.20 & 0.036 & 0.19 \\
\hline Other Asia & 0.045 & 0.21 & 0.046 & 0.21 & 0.040 & 0.20 \\
\hline Africa & 0.067 & 0.25 & 0.058 & 0.23 & 0.111 & 0.31 \\
\hline C. \& S. America & 0.056 & 0.23 & 0.043 & 0.20 & 0.121 & 0.33 \\
\hline Sample Size & \multicolumn{2}{|c|}{19,894} & \multicolumn{2}{|c|}{16,542} & \multicolumn{2}{|c|}{3,340} \\
\hline
\end{tabular}

\footnotetext{
(a) = Excludes the Atlantic Provinces. See text for explanation.

(b) = Variable not relevant.

(c) = Distance variable for Quebec defined with reference to Montreal; for the total sample and English Canada it is the smaller of the distance from Toronto and Vancouver..

Source: 1991 Census of Canada, Public Use Microdata File (Individuals)
} 
Appendix Table B-4

Reduced Form Multinomial Logit Model of Language Practice, Male Immigrants who Completed Their Education Overseas, 25-64, Canada, 1991 Census of Canada

\begin{tabular}{|c|c|c|}
\hline Variable & $\overline{\log (\mathrm{L} 2 / \mathrm{L} 1)}$ & $\overline{\log (\mathrm{L} 3 / \mathrm{L} 1)}$ \\
\hline Constant & $\begin{array}{r}1.724 \\
(479)\end{array}$ & $\begin{array}{l}1.685 \\
(4.27)\end{array}$ \\
\hline Age & $\begin{array}{c}-0.055 \\
(13.53)\end{array}$ & $\begin{array}{l}-0.079 \\
(17.13)\end{array}$ \\
\hline Educational Attainment & $\begin{array}{c}0.239 \\
(26.60)\end{array}$ & $\begin{array}{c}0.393 \\
(39.30)\end{array}$ \\
\hline Period of Residence (PER) & $\begin{array}{l}0.049 \\
(3.65)\end{array}$ & $\begin{array}{l}0.118 \\
(8.30)\end{array}$ \\
\hline PER Squared/100 & $\begin{array}{l}0.092 \\
(2.60)\end{array}$ & $\begin{array}{l}0.099 \\
(2.67)\end{array}$ \\
\hline Province (Ontario): & & \\
\hline Atlantic & $\begin{array}{l}0.172 \\
(0.17)\end{array}$ & $\begin{array}{l}0.577 \\
(0.56)\end{array}$ \\
\hline Quebec & $\begin{array}{l}0.407 \\
(3.60)\end{array}$ & $\begin{array}{l}0.646 \\
(5.48)\end{array}$ \\
\hline Prairie & $\begin{array}{l}0.036 \\
(0.31)\end{array}$ & $\begin{array}{l}0.403 \\
(3.27)\end{array}$ \\
\hline British Columbia & $\begin{array}{r}0.137 \\
(1.21)\end{array}$ & $\begin{array}{l}0.463 \\
(3.87)\end{array}$ \\
\hline Lives in CMA & $\begin{array}{l}-0.163 \\
(1.04)\end{array}$ & $\begin{array}{l}-0.734 \\
(4.59)\end{array}$ \\
\hline Married & $\begin{array}{l}0.327 \\
(3.08)\end{array}$ & $\begin{array}{l}-0.316 \\
(2.82)\end{array}$ \\
\hline Refugee & $\begin{array}{l}-1.074 \\
(7.41)\end{array}$ & $\begin{array}{l}-2.428 \\
(14.36)\end{array}$ \\
\hline Colony & $\begin{array}{l}1.051 \\
(6.72)\end{array}$ & $\begin{array}{l}0.810 \\
(4.81)\end{array}$ \\
\hline Minority Language & -0.115 & -0.204 \\
\hline Concentration & (7.68) & (12.49) \\
\hline Linguistic Distance & $\begin{array}{l}-2.075 \\
(5.30)\end{array}$ & $\begin{array}{l}-7.492 \\
(17.44)\end{array}$ \\
\hline Miles Origin Country From & 0.024 & 0.180 \\
\hline Canada/1000 & $(0.50)$ & $(3.51)$ \\
\hline Log Weeks Worked & $\begin{array}{l}0.123 \\
(2.03)\end{array}$ & $\begin{array}{l}0.343 \\
(5.05)\end{array}$ \\
\hline Citizen & $\begin{array}{c}0.881 \\
(10.15)\end{array}$ & $\begin{array}{c}1.040 \\
(11.18)\end{array}$ \\
\hline $\begin{array}{l}\text { Sample Size } \\
\chi^{2}\end{array}$ & \multicolumn{2}{|c|}{$\begin{array}{l}19,894 \\
6555.5\end{array}$} \\
\hline Pseudo $\mathrm{R}^{2}$ & \multicolumn{2}{|c|}{0.1932} \\
\hline
\end{tabular}


Note: $\mathrm{L} 1=$ Speaks neither English nor French; L2 $=$ Speaks an Official Language but usually speaks a non-Official language at home; L3 = Speaks an Official language and usually speaks an Official language at home.

Asymptotic ' $t$ ' statistics in parentheses.

Note: Birthplace variables are not included in the reduced form as the Refugee, Colony and Miles Origin Country from Canada variables are each linearly related to the birthplace variables, and the Minority Language Concentration and Linguistic Distance variables are constructed, in part, using information on birthplace.

Source: 1991 Census of Canada, Public Use Microdata File (individuals). 


\section{IZA Discussion Papers}

No. Author(s)

436

A. Kunze

437

M. Fertig

438

439

440

441

442

445

446

447
R. Lalive

J. Zweimüller
A. Voicu

G. Fella

P. Manzini

M. Mariotti

G. Bertola

S. Hochguertel

W. Koeniger

C. W. Sibley

P. P. Walsh

M. Lindahl

K. L. Papps

J. O. Newell

G. S. Epstein

E. Yashiv

M. Fertig

C. M. Schmidt

M. P. Keane

E. S. Prasad

B. R. Chiswick

P. W. Miller

B. R. Chiswick

Y. Liang Lee

P. W. Miller

B. R. Chiswick

P. W. Miller
Title

Area

Date

The Evolution of the Early Career Gender Wage $\quad 1$

Gap

Evaluating Immigration Policy Potentials and Limitations

Employment Dynamics in the Romanian Labor Market: A Markov Chain Monte Carlo Approach

Does Divorce Law Matter?

Dealer Pricing of Consumer Credit

Earnings Inequality and Transition: A Regional

Analysis of Poland

Estimating the Effect of Income on Health and Mortality Using Lottery Prizes as Exogenous

Source of Variation in Income

Identifying Functional Labour Market Areas in

New Zealand: A Reconnaissance Study Using

Travel-to-Work Data

Benefit Entitlement and the Labor Market:

Evidence from a Large-Scale Policy Change

Informational Cascades and Decision to Migrate

Macroeconomic Policy Lessons of Labor Market

Frictions

Mobility within Europe - What do we (still not) know?

Inequality, Transfers and Growth: New Evidence 4 from the Economic Transition in Poland

Do Enclaves Matter in Immigrant Adjustment? $\quad 1$

Schooling, Literacy, Numeracy and Labor Market Success

The Complementarity of Language and Other Human Capital: Immigrant Earnings in Canada
6

4

$02 / 02$

$02 / 02$

6

$02 / 02$

03/02

03/02

6

03/02

03/02

03/02

03/02

2/02

2/02

$2 / 02$

2/02

$2 / 02$

2/02

1

1

03/02

An updated list of IZA Discussion Papers is available on the center's homepage www.iza.org. 